\title{
Mitska krajina: razmisleki in smernice za Mitski park
}

\section{Katja Hrobat Virloget}

Univerza na Primorskem

katja.hrobat@fhs.upr.si

\section{Uvod: o spominu v prostoru in bistvu verovanja}

Da lahko danes raziskovalci sploh pišemo o mitskih krajinah, ki predstavljajo nek palimpsest preteklih verovanj in percepcij sveta, se lahko zahvalimo ohranjanju kolektivnega spomina v krajini. Prvo vprašanje, ki se nam tako zastavi, je, zakaj in kako se spomin ohranja v prostoru. Kako da se ravno prek pripovednega izročila, ki se navezuje na določena mesta v krajini, lahko še danes ukvarjamo z mitsko krajino?

Pomen prostora v konstrukciji kolektivnega spomina je prvi opazil sociolog Maurice Halbwachs. Ugotovil je, da se kolektivne identitete strukturirajo okoli časovno-prostorskih referenc, ki utrjujejo spomin skupne preteklosti (Halbwachs 1971). Da se lahko določena resnica fiksira v spomin skupine, se mora predstaviti v konkretni obliki nekega dogodka, osebe ali kraja (Halbwachs 1971, 124). Primer je krščanski kolektivni spomin, ki se je vpisal v kraje Svete zemlje, zato da bi priskrbel iluzijo trajnosti. Ta ni nastal iz direktnih pričevanj, temveč v skupnosti, oddaljeni od Svete zemlje, ki si je v odsotnosti doživljanja sprememb v prostoru o njem ustvarila lastno simbolno reprezentacijo. Stabilnost, ki omogoča trajanje verovanj, ni v materiji sami, ki je spremenljiva, temveč v podobi, zamenjani s samo sabo. Od Palestine oddaljeni kristjani si lahko v spomin prikličejo Jeruzalem kljub temu, da njihova podoba ne ustreza realnosti. Podobi se namreč ni treba prilagajati realnosti, temveč verovanjem. Za predmet kolektivnega spomina je tako značilna dvojnost: po eni strani se naslanja na materialno danost, figuro, kraj, spomenik, po drugi strani pa na simbol, duhovni pomen, ki se v duhu skupine zasidra in naloži na to realnost (Halbwachs 1971, 117-164). Skupine tako svoje oblike rišejo na tla, kjer tudi zapirajo in najdevajo svoje kolektivne spomine (Halbwachs 1971, 130; 2001, 143-77). Spomin skupnosti o sami sebi se osredotoča na specifičnost skupine $v$ kontrastu do drugih in na kontinuiteto $v$ času. Na področju trajanja se skupnost dojema, če ne kot "večna«, pa vsaj kot nespremenljiva v svo- 
jem bistvu (Halbwachs 1971). Zato "ni kolektivnega spomina, ki se ne bi dogajal v prostorskem okviru, [...] saj nam daje [...] zgolj podoba prostora zaradi svoje stabilnosti iluzijo, da se skozi čas sploh nismo spremenili in da najdemo preteklost v sedanjosti (Halbwachs 2001, 157, 176). V materialni ureditvi življenjskega okolja se je utelesil namen nekdanjih ljudi, zaradi česar bi vsakršen premik ali izbris $\mathrm{v}$ prevzeti konfiguraciji prostora pomenil izgubo opore za tradicijo, ki priporoča skupino, se pravi izgubo edinega razloga za obstoj (Halbwachs 2001, 150-151; Hrobat 2010a, 36-37).

Halbwachsovo idejo, da je religiozni kolektivni spomin, ki se umešča $v$ "stabilnost materialnih stvari« preko simbolov, mogoče izbrisati le s fizičnim uničenjem kraja izvajanja kulta (Halbwachs 2001, 150-151, 172-173), nazorno pokaže primer ljudstva Bororo iz Brazilije. Claude Lévi-Strauss je opazil, da je celotna tradicija ljudstva predstavljena v strukturi krožne vasi. Zapleteno načelo delitve vasi na dve polovici s središčno moško hišo in razvrstitvijo klanov je urejalo celo vrsto socialnih vidikov in kultnih praks, od poroke in pogrebov do pravil druženja, dedovanja itn. Misijonarji so sprevideli pomen strukture za ohranjanje tradicij in spoznali, da je najprepričljivejše orodje pokristjanjevanja razbitje prostorske strukture - da Bororci zapustijo svoje vasi in se preselijo $\mathrm{v}$ vasi $\mathrm{z}$ vzporednimi hišami. Brez prostorske fiziognomije, $\mathrm{v}$ katero niso več umeščene njihove kompleksne tradicije, se zdi, da so bili ljudje oropani načrta in so tako hitro izgubili stik s tradicijo (Lévi-Strauss 2004, 207-214; Hrobat 2010a, 37).

Na kontinuiteto tradicij v prostoru se je naslonilo krščanstvo. Tako je bila rimska poganska dediščina uporabljena kot medij za ojačitev avtoritete papeža. Tradicije namreč niso statične in se prilagajajo zunanjim zahtevam (Harvey 2001, 331). Ta ideja kontinuitete in nadzora določene dediščine je jasna iz navodila sv. Gregorja Velikega, ki je krščanske misijonarje pozval, "naj očistijo poganska svetišča in jih uporabijo kot cerkve ${ }^{1}$ (Harvey 2001, 331). Tudi pri vzpostavljanju ideje Svete dežele se je krščanske spomine vsakič znova umestilo vanjo, kljub temu, da so bili pred tem ti že zabrisani (recimo v času zasedbe muslimanov). Krščanski spomin je vsakemu obdobju prilagajal svoje spomine na podrobnosti Kristusovega življenja in na kraje, na katere so prilepili sodobne potrebe krščanstva. Krščanski spomini so se umestili v starejše židovske lokalizirane spomine, s čimer je bil v začetkih krščanstva omogočen obstoj krščanske tradicije. Sčasoma je ravno z umestitvijo $\mathrm{v}$ starejšo tradicijo krščanski kolektivni spomin pridobival na avtoriteti, prestižu. Preroki sv. Abraham, sv. Jakob in Mojzes so tako do-

\footnotetext{
${ }^{1}$ Angleška beseda cleanse je verjetno uporabljena figurativno v pomenu očistiti greha.
} 
bili krščansko svetost, od judovskega pa so ohranili le toliko, kolikor daje verjeti, da je krščanstvo pognalo korenine iz starejše, hebrejske tradicije (Halbwachs 1971, 117-164).

Umeščanje novih tradicij $\mathrm{v}$ starejšo dediščino $\mathrm{z}$ namenom prilaščanja oziroma pridobivanja avtoritete $\mathrm{v}$ sodobnosti je mogoče zaslediti $\mathrm{v}$ vseh časih in pri mnogih političnih ter religioznih sistemih (Harvey 2001). O enakem priča epigrafski napis iz baze kipa cesarja Avgusta (14. st. n. št.) v bližini Rodika, v Škocjanu, pri čemer beseda sacrum na njem odraža vladarski kult. Rimska državna religija se je $s$ tem umestila v prostor $z$ izjemno močno prazgodovinsko kultno tradicijo in ga s tem simbolno ter ritualno obvladala (Slapšak 1999). Podobno izrabo simbolne moči dediščine za sodobne potrebe je moč zaslediti tudi v ustnem izročilu. Pri t. i. starovercih iz Posočja (Hrobat Virloget 2019, 25-26) tako, recimo, preberemo, da je bila cerkev sv. Jakoba na hribu pri vasi Zapotok zgrajena na predkrščanskem sončnem svetišču po imenu Škeljak. Sveti kamen s podobo sonca in lune ter s kamnitim risom okrog so razbili, namesto njega pa danes stoji cerkveni oltar (Medvešček 2015, 332). Nič nenavadnega ni zaznati nalaganja kultnih plasti na enem mestu prek daljšega časa trajanja (Pleterski 2014), kar pa je zanimivo pri staroverskem izročilu, pa je to, da se je spomin na to tudi ohranil.

Pri tem nalaganju različnih simbolnih kultnih plasti eno na drugo ne gre le za nove tradicije, ki se usidrajo v preteklo dediščino, temveč pogosto za njihov soobstoj. Nekateri so pri slovanski mitologiji to imenovali dvojeverje (Pleterski 2014, 140; Belaj 1998, 120). Drugi raziskovalci pri prepletu krščanskih in staroselskih tradicijah govorijo o kulturnih hibridih in paradoksih, ki po eni strani odražajo konflikt med različnimi verovanji, kontinuiteto, po drugi pa prekinjajo s tradicijo in porajajo nove oblike verovanj (Severi 2015, 291-326).

Paul Veyne je že pri antičnih Grkih pa tudi za sodobnost argumentiral, da gre za različne resničnostne programe, pri čemer namesto o verovanjih govori o resnicah. Raziskovalec antične mitologije razmišlja o pluralnosti načinov verovanja ali pluralnosti meril resnice. Kot pomenljivo pripomni, "Grk je postavil bogove sna nebo<, bil bi pa hudo presenečen, če bi jih tam zares opazil« (Veyne 1998, 33). Vendar gre v tem primeru bolj za vprašanje različnih resničnostnih programov, ki se ne mislijo na isti ravni. Strah pred prikaznimi je namreč drugačen kot strah pred psom, saj gre za strah pred vdorom nekega drugega sveta, $s$ katerim se tudi $\mathrm{z}$ današnjimi znanstvenimi orodji ne moremo spopasti (Veyne 1998, 39-40, 127). Kot je nekdo pripomnil pri pogovoru o strahu ponoči na pokopališčih, »ker nikoli ne veš, 
kaj se bo zgodilo«. (Hrobat 2010a, 27, 32) Zato človek na kraju, kjer pravijo, da straši, raje pospeši korak, zato se nekaterim zdi, da jih je umrli prišel pozdravit, ${ }^{2}$ in zato se ponoči raje izogibamo pokopališč (Hrobat 2010a, 32). Človek je od vedno soočen $\mathrm{z}$ dvomom, pa čeprav naj bi danes prevladala resnica, ki jo imenujemo znanstvena, racionalna. Pa vendar se človek očitno težko odloči za eno samo resnico oziroma, kot bi resnico $v$ angleščini poimenovala Mattijs van der Port in Birgit Meyer (2018, 2), world-making ali kulturno konstrukcijo resničnosti. In prav napetost med sprejemanjem in dvomom je po Carlu Severiju (2015, 207-228, 242-243) bistvo vsakršnega dejanja verovanja. V nasprotju s splošno veljavnim prepričanjem pri verniku nikoli ne najdemo gotovosti. Severi, recimo, komentira raziskavo o evropskem srednjeveškem čarovništvu Carla Ginsburga (1966), kjer obtoženci pred sodiščem definirajo verovanja na negativen način: »Ne vem, ali čarovnice obstajajo."S priznanjem, da ne vedo, ali čarovnice res obstajajo, $\mathrm{v}$ resnici ne zanikajo krščanskih verovanj, ampak hkrati priznavajo obstoj "nadnaravnih ${ }^{3}$ bitij in jih postavljajo v nek nejasen prostor nekje med verovanjem in neverovanjem, v območje "morda verovanja (angl. perhaps belief). Pri naravi verovanja gre tako bolj za dvom v obstoj kot za prepričano vedenje.

Različni resničnostni programi so prepoznavni tudi v vprašanjih verovanja še pred nedavnim oziroma pri dilemi, kateri verovanjski sistem je »bolj pravi«. Tako naj bi ob naročilu apotropejskih simbolov na kamnitih kolonah v Lokvi na Krasu ljudje klesarju naročili izdelavo obeh tipov simbolov, »krščansk[ih] in on [ih] po običaju« (Čok 2015, 106). Tako so navadno naročali križ na sredini, na oba stebra pa »ta stare« simbole, med katerimi naj bi imel vsak svojo funkcijo varovanja, od hiše in ljudi do živali (Čok 2015, 106107). To »plastenje« oziroma prepletanje različnih verovanjskih sistemov je konstantni del verovanjskih praks. Primer tega jasno pokaže Peter Jordan v raziskavi svete krajine pri ljudstvu Khanti v Sibiriji. Opaža namreč, da se ljudje gibljejo med različnimi verovanjskimi diskurzi in fluidnimi identitetami, ki so priklicani v različnih časih in $\mathrm{v}$ različnih kontekstih. Tako se njihova domovanja, jurte, kažejo kot najbolj kozmopolitska, najbolj na-

\footnotetext{
${ }^{2}$ Poleg izročila, popisanega v Hrobat (2010a) mi je tudi gospa iz Lucije v intervjuju povedala za doživetje, ko jo je kot otroka prišel pozdravit umrli oče. To videnje jo je pomirilo oziroma rešilo otroških strahov, ko jo je bilo pred tem velikokrat strah neke nenavadne sence. Intervju, opravljen 4. 7. 2014, hranjen v osebnem arhivu.

${ }^{3}$ Pojem "nadnaravno« postavljam v narekovaj, saj gre pogosto le za kategorijo znanstvenega diskurza, ki se ne nujno ujema s predstavami preučevanih, ki »nadnaravnega» in »naravnega« ne ločijo na isti način (glej razpravo v nadaljevanju in Mencej 2019).
} 
videzno pravoslavno ruska, vendar s skrito dimenzijo tradicij Khanti, najsvetejši kraji so najbližje tradicijam Khanti, medtem ko je pokopališče $s$ simboli pravoslavnih križev in ptic po tradiciji Khanti nekje vmes (Jordan 2003, 95, 229). Ta krščanska prevleka, ki preplasti »domače« tradicije, je razvidna tudi pri t. i. starovercih iz Posočja. O tem priča tudi podatek, da je bila fasada hiše edinega lokalnega svečenika, dehnarja, prekrita s krščanskimi freskami. ${ }^{4}$

\section{Mitska krajina}

\section{"Nadnaravno", krščanstvo in lintver}

Na primeru rodiške mitske krajine poskušajmo nadaljevati razpravo o verovanjih, "plastenju « različnih verovanj in o različnih resničnostnih programih, ki so tudi bistvo razstave v Centru za obiskovalce v Rodiku. ${ }^{5} \mathrm{Na}$ razstavi smo odprli razpravo o različnih sočasnih doživljanjih sveta oziroma resničnostnih programih, od znanstvenega in mitskega/religioznega do umetniškega. V sodobni zahodnjaški družbi vlada avtoritativnost enega samega pogleda kot edinega glasnika resnice, ki je znanstvena, s čimer se vse druge poglede na svet izključuje kot »neresnične« oz. »neverodostojne«. Postavitev sledi Einsteinovi misli, da so religija, znanost in umetnost le različni vidiki iste resničnosti. Znanost $\mathrm{v}$ razstavi ni postavljena na piedestal, kot običajno je $\mathrm{v}$ zahodnem svetu, temveč na isto raven kot drugi dve resničnosti, tj. umetnost ter mitsko izročilo, ki sta v ospredju razstave. Skozi razstavo spremljamo različne poglede na svet, na preteklost, naravo, smrt itd., ki se tekom časa spreminjajo, ampak tudi soobstajajo kot avtorizirani in marginalni diskurzi, kot npr. znanost in sodobna gibanja new age. Znanstvene, psevdoznanstvene, religiozne in mitske interpretacije rodiške mitske krajine na koncu nadgrajuje mednarodno priznani U N E S CO-V umetnik za mir Marko Pogačnik s svojo umetniško vizijo, ki temelji na geomantičnih raziskavah (Pogačnik 2020; Hrobat Virloget 2020, 27).

Vprašanje, ki se med drugim zastavlja tudi na razstavi in ki ga srečamo pri večini pripovednega izročila v Rodiku, je obstoj t.i. "nadnaravnega«. Postavlja se vprašanje, koliko je izraz "nadnaravno « zgolj izmišljen znanstveni koncept, ki ustreza definiciji naravnega $z$ vidika ene same, znanstvene, resničnosti. Pri raziskovanju čarovništva se npr. folkloristka Mir-

${ }^{4}$ Podatek iz pogovora s Pavlom Medveškom in kustosinjo Darjo Skrt v času razstave o starovercih v Goriškem muzeju.

${ }^{5}$ Vsebinski koncept in besedila razstave smo pripravile Katja Hrobat Virloget, Ana Plestenjak in Neža Čebron Lipovec, oblikovalci so Zavod t RA N S, Sanja Jurca Avci, Tomaž Budkovič in Dolores Gerbec, vse pod finančnim nadzorom Ester Mihalič iz Občine Hrpelje-Kozina. 
jam Mencej sprašuje, koliko koncept "nadnaravnega odseva emsko perspektivo, torej koliko so ljudje verjeli, da gre pri čarovniških dejanjih za (izključno) »nadnaravna«. Ugotovila je, da ljudje v resnici niso jasno ločili med "naravnimi« in "nadnaravnimi« dejanji, oba tipa dejanj sta bila dojeta kot čarovniška (Mencej 2020, 144, 155). Pri vprašanju soobstoja dveh konceptov verskega pogleda na svet $\mathrm{v}$ okviru raziskave »nadnaravnih « bitij v Dalmaciji folklorist Luka Šešo razmišlja, da je Cerkev prav s svojo bitko proti »nadnaravnim « bitjem potrjevala njihov obstoj, pa čeprav jih je uradno negirala in prepovedovala verovanja v njih. V boju proti "nadnaravnim " bitjem so bili vpleteni duhovniki in mnoge cerkvene ter krščanske prakse, kot so molitve, plačevanja maš, posvečena voda ipd. Že cerkveno priznanje obstoja padlih angelov $\mathrm{z}$ "nadnaravnimi« močmi, ki se pretvorijo v zla bitja, hudiče, priča o tem, da »nadnaraven «ni le krščanski Bog. Obstoj drugih "nadnaravnih« bitij je Cerkev priznavala z bojem proti čarovnicam, volkodlakom in drugim bajeslovnim bitjem. Izpoveden je primer hriba pri Donjih Raštanih, kjer so ljudje v želji pred tem, da bi se ubranili zlih namenov štrig, ki naj bi se na hribu zbirale in strašile, nanj postavili kapelico Matere Božje. V želji po izkoreninjanju poganskih verovanj je Cerkev potrdila njihov obstoj, pri čemer je poudarila njihovo povezavo s hudičem, proti kateremu se lahko bori le Cerkev (Šešo 2016, 248-262).

Tudi v Rodiku je Cerkev ravno s svojo lastno bitko proti »nadnaravnemu« bitju priznavala njegov obstoj. Duhovnik Matija Sila namreč omenja krščanske procesije vrh hriba Čuk k Jezeru (slika 1), »da so hudobo zarotili: 'Gospodine! Zateri ga in ubi ga, onega vraga, ki tu prebiva!‘, kajti od ondi je prihajala večkrat nevihta." (Sila 1882, 42) Po pričevanjih Matije Sile je bilo do leta 1787 na hrib Čuk do 21 procesij letno, in sicer iz Rodika in Brezovice. Še v 19. stoletju pa so te šege živele le še v spominih in skromnih materialnih ostankih. Obred blagoslavljanja Jezera (zapisano v kroniki kot jus paludem benedicendi), ki ga je vodil župnik iz sosednje vasi in fare Brezovice, je potekal ob kamnu z vklesanim križem, od katerega je bil po zapisu leta 1859 viden le še en kos (Slapšak 1997, 20; Peršolja 2000, 196; Hrobat 2004, 63-64; Medeot, Crevato in Margon 2021). »Nadnaravno « bitje je tako jasno izenačeno $\mathrm{z}$ zlom, s hudičem, ki ga je Cerkev zaradi povzročanja naravnih nesreč poskušala izkoreniniti s krščanskim obredjem, s čimer je zgolj potrdila njegov obstoj in ga demonizirala. Zaradi neposredne bližine antičnega grobišča Pod Jezerom bi lahko v preživetju »nadnaravnega« bitja in pokristjanjenju njegovega mesta sklepali, da je bilo mesto izvorno povezano $\mathrm{z}$ nekim predkrščanskim kultom prebivalcev Ajdovščine nad Rodikom. Pomenljivo se zdi tudi to, da sta $\mathrm{v}$ tradicijskih verovanjih kača (lintver) in 


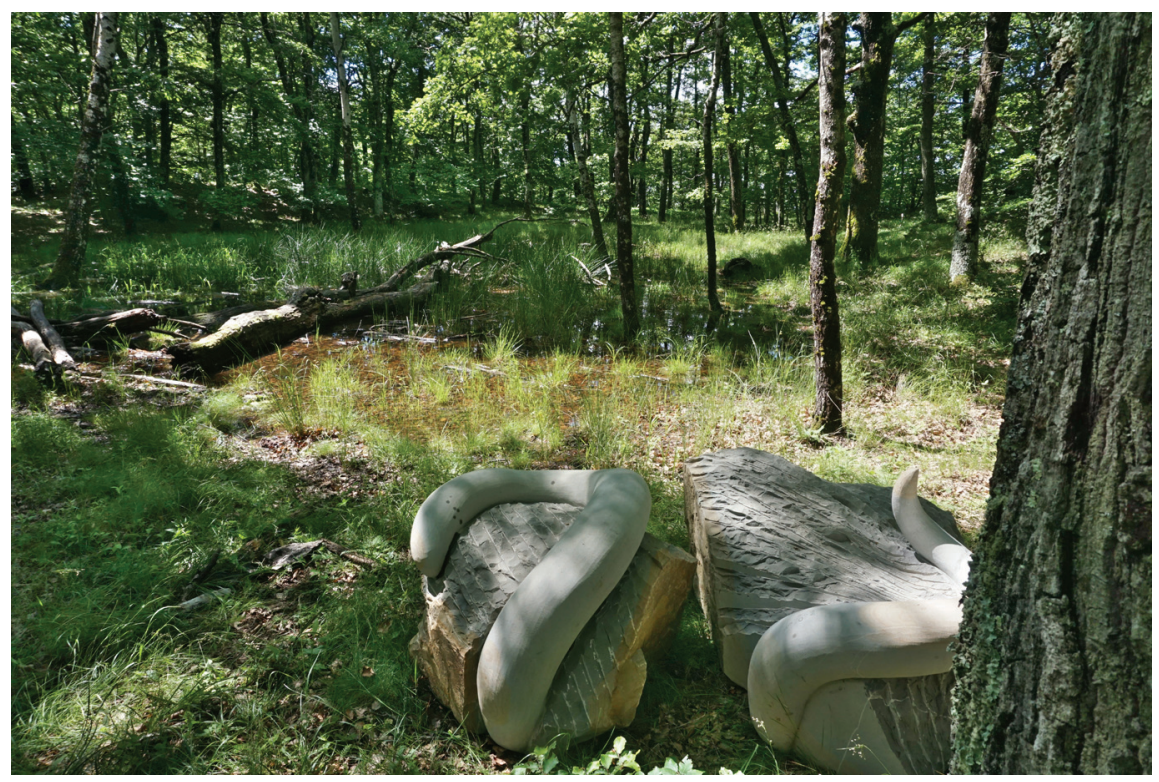

Slika 1 Na Jezeru s skulpturo lintverja Špele Šedivy, pred njo vidna voda, ki občasno tudi izgine, ter za njo umetno narejen nasip (avtorica fotografije Katja Hrobat Virloget)

voda (Jezero) pogosto povezana s kultom mrtvih oziroma prehodom $\mathrm{v}$ svet mrtvih. Sicer se pojavlja tudi vprašanje, ali je oblika kače kot lintverja, imenovanega tudi kačon, izvorna ali je to krščanska vizualna oblika demonizacije, vedoč, da je bila kača s krščanstvom spremenjena v simbol zla (Hrobat 2004). Dodaten indic za interpretacijo o predkrščanskem kultnem mestu je tudi umeten nasip okrog Jezera, predvsem pa kamniti apnenčasti bloki pod njim (Medeot, Crevato in Margon 2021, slika 5), v katere je bilo vloženega veliko človeškega truda, da so jih pripeljali na vrh hriba povsem drugačne kamninske sestave, iz peščenjaka in laporovca (Kovačič 2021; Medeot, Crevato in Margon 2021). Zanimivo je opaziti, da ima kraj še danes negativno konotacijo zlega, strašljivega, saj mi je domačin, ki sem ga še leta $2020 \mathrm{~V}$ skupini vodila do Jezera, povedal, da še nikoli ni bil na tem kraju, saj so se ga Rodičani vedno izogibali.

Gledano s perspektive slovanskih verovanj bi lahko demonsko bitje, ki $z$ vrha gore ustvarja strele in nevihte, po značilnostih spominjalo tudi na slovansko božanstvo Perun, seveda v svoji demonizirani obliki. ${ }^{6}$

\footnotetext{
${ }^{6} \mathrm{~V}$ rodiškem izročilu bi lahko s Perunom povezali nenavadno izročilo o Mariji Ognjenici,
} 
Na izročilo o Čuku kot hribu, polnem vode, spominja vrsta votlih gor, polnih vode, kot so Boč, Sv. Jošt, Konjiška gora, Gorjanci (Šmitek 2004, 48-49). Rodičani delu pod Ajdovščino pravijo Gura, medtem ko v Franciscejskem katastru Ajdovščine ni, je pa namesto nje in $350 \mathrm{~m}$ severno od vrha ledinsko ime Na Hora (Na gori), kar je z vidika vidnosti arheološkega naselja Ajdovščine čudno, in sicer da ni bila poimenovana oziroma pokazana piscem katastra v 19. stoletju (Kovačič 2021). Vitomir Belaj in Juraj Belaj (2014, 164) ter Radoslav Katičić (2008) domnevajo, da Gora v mitski krajini pogosto nastopa kot ime, ki poudarja splošne mitske značilnosti, v smislu Gore nad gorami, na kateri živijo bogovi kot središče sveta, oziroma kot pri Potoku pri Trebišćih, ki spominja na vse potoke. Na Krasu je poznanih kar nekaj Gor s takim pomenom (npr. Nanos, Vremščica; Gura nad Plešivico), katerih izročila nakazujejo na svetost oziroma na predkrščanska ali krščanska kultna mesta vrh njih (Hrobat 2010a, 148-154; Čok 2012, 103). Vprašanje je, ali je tudi ta Gora/Gura povezana z nekim posebnim pomenom, morda bolj v navezavi na ajdovske mitske prednamce.

\section{Slovanska mitska krajina v Trebišćih pri Mošćenički Dragi}

Zelo jasen spomin na nebeško (pra)slovansko božanstvo najdemo v hribu Perun v hrvaškem delu čezmejnega Mitskega parka, ki stoji ravno nad vasjo po imenu Trebišća. V stari ruski cerkveni književnosti se pogosto omenjata Perun in njegovo trebišće, kar označuje mesto, na katero se mu prinaša treba, kar je praslovanska beseda za "žrtev« (Katičić 2008, 306). Nadgradnja hipoteze o povezavi Trebišć s Perunom je tudi mlin v zaselku, od katerega imajo pomembno vlogo mlinski kamni, s katerimi naj bi v slovanskem mitskem izročilu Perun povzročal grmenje. Tretja točka mitske krajine je Veles kot (pra)slovansko božanstvo podzemlja in imetja, živine, ki bi ga lahko glede na izročilo o hudiču, ki se poleg zmaja in kače pogosto uporablja za upodobitev Velesa, umestili v jame pod vasjo Potoki pod Perunom. Na tem mestu, kilometer vzhodno od Trebišća, se nahaja stena na izviru Potoka s pomenljivim imenom Voloski kuk. Podobno ime je Volosko na obali med

ki z ognjem omogoča kaljenje žita v marcu (Hrobat 2010a, 96-97). V Rodiku so pravili, da "Marija wognjenica utkne glovnjo u zemljico. Tisti dan morajo rodiški otroci tekati bosi okrog ognja pri Pili, na sredi Pula. Marija Ognjenica ima god 23. marca. Šele ko je sglovnjar zemljo segrela, so Rodičani orali in sejali.« (Po pisnem sporočilu Jasne Majde Peršolja, 21. 10. 2020, del izročila povedal pokojni Klavdijo Babuder-Mrkelov.) Izročilo spominja na Ognjeno Marijo iz Srbije in Bolgarije, ki velja za ženski korelat Peruna (Šmitek 2004, 119; Hrobat 2010, 96-97). Tudi tu je opazen pomen izročila v krajini, ko torej neko obredno dejanje deluje, ko je postavljeno na pravo mesto $\mathrm{v}$ krajini. 
Reko in Opatijo. Pri tem je vprašanje, ali obe imeni nimata zveze z imenom slovanskega Velesa ali se pri razlagi imena napačno uporabljajo fonetični zakoni. Vprašanje je, zakaj se staro rusko ime Volos za Velesa ne pojavlja nikjer drugje na južnoslovanskem in zahodnoslovanskem območju, kjer se pojavljajo le toponimi tipa Veles (Katičić 2008, 311-312; Belaj in Belaj 2014, 159-160). Na tem mestu so tri jame, kar ustreza predstavi, da je Velesovo mesto $\mathrm{v}$ votlini, pri korenu hrasta, v jami pod goro, dol pri vodi. Ena od jam, Potuklica, v izročilu velja za mesto "nadnaravnih« sil. Po pripovedi naj bi na njenem vhodu v času procesije na telovo hudič nosil zlato, da bi ga sušil na soncu. Še živi pričevalci so tudi govorili o tem, da jih je pri iskanju zlata v tej jami nekaj močno prestrašilo, nekaj »nadnaravnega«, zaradi česar naj bi se vrnili domov plešasti. Zanimivo, da je jama nasproti Perunove gore in ne direktno pod njo, kar Radoslav Katičić pojasnjuje s tem, da je za razliko od ostalih jam ta osončena, torej primerna za sušenje zlata. Znano je, da se Veles v krščanski ikonografiji pojavlja kot hudič. Njegovo bogastvo je živina, imetje, potemtakem tudi zlato. Kot kažejo ruska poganska zaklinjanja Grkom v starem letopisu, Veles lahko vse pozlati. V tej sakralni krajini imamo tako osnovne elemente slovanske mitologije: goro Perun, pod njo Velesovo vodo spodaj, pod Gromovnikovo goro, mesto darovanja izpod gore, kjer je hkrati tudi mlin na vodi, kjer je v sakralni interpelaciji mesto, kjer Gromovnik s kamnom ubije zmaja, Velesa (Katičić 2008, 305-312). Tretji element širše mitske krajine bi lahko bilo žensko božanstvo po imenu Baba, interpretirano kot praslovansko božanstvo Mokoš. Po eni izmed interpretacij ga lahko prepoznamo v toponimu Babin grob, ki leži na vrhovih Učke pod Velbatom in Suhim vrhom, pri čemer je tudi slednje pogosto mesto Peruna (Katičić 2008, 312; Belaj in Belaj 2014, 159, 165).

Po drugi interpretaciji naj bi se žensko božanstvo nahajalo izven parka, na rtu Volosko v cerkvi Blažene Device Marije na Trsatu (Belaj in Belaj 2014, 163-164). Vitomir in Juraj Belaj nakazujeta več mitskih krajin okrog Peruna nad Trebišći, pri čemer je pomembno to, da so točke med seboj $\mathrm{v}$ vizualnem kontaktu, ena je mikrovzorec z Mošćeničkim Perunom in Potokom pod njim, druga pa je širši vzorec, kjer je hrib Perun eden od členov. V vizualnem kontaktu je Perun tudi s hribom Perunčevac, ki je ravno nad Gračišćem v Istri, v zvezi s katerim bo v nadaljevanju omenjena najstarejša Baba v cerkvi Device Marije (Vince-Pallua 2018), in celo s paškim sv. Vidom, tudi točko slovanske mitske krajine. Še en makrotrikotnik avtorja imenujeta liburnijski, in sicer med Perunom, Voloskim in Trsatom. Čeprav je pri slednjem kot večji od t. i. obrednega kota $23^{\circ}$, saj obsega $26^{\circ}$, pravita, da ima pravilo lahko tudi odstopanja (Belaj in Belaj 2014, 178). Av- 
torja namreč potrjujeta hipotezo Andreja Pleterskega na več primerih, in sicer da se mitske točke povezujejo v trikotnik, kjer se ponavlja kot $23^{\circ}$. Ta je enak kotu med osjo Zemljinega vrtenja in pravokotnico na ravnino Zemljine orbite okoli Sonca. Zaradi tega kota imamo med drugim letne čase ter enakonočji in sončna obrata kot skrajnosti. Na simbolni strani ta kot označuje razmerje $1: \sqrt{2}$. Smisel simbolike Pleterski prepoznava v vzpostavljanju razmerij med božanstvi kot utelešenju naravnih sil in s tem doseganju pravilnega ravnotežja narave (Pleterski 2014, 11-12; Belaj in Belaj 2014, XVIII). Hipoteza je bila sicer deležna kritike (Bilić 2020), vendar o tem poteka diskusija (Pleterski v tisku). Stranica tega t. i. liburnijskega kota sega iz vrha Peruna v kanjon Rječine, kjer naj bi bilo pod impozantno trsatsko steno Velesovo mesto, a nad njo je pomenljivo postavljena cerkev sv. Jurija, po rekonstrukciji slovanske mitologije Velesovega posinovljeneca. Izročilo se na tem mestu navezuje tudi na Marijo, ki naj bi se zaradi brezbožnosti umaknila drugam, pri čemer se postavlja vprašanje, če brezbožno pomeni pogansko. Volosko je tako točka Mokoš, pri čemer avtorja ugotavljata, da ime nima mitskega ozadja, temveč izhaja iz volov, ki so tam pretovarjali blago. Mokoš je tako v mitskem trikotniku skupaj s Perunom od Velesa ločena $z$ vodo (Belaj in Belaj 2014, 157-166). Zdi se, da je povezav znotraj mitske krajine res lahko več, na kar med drugim nakazuje tudi toponim, ki sem ga opazila v Ekomuzeju Mošćenička draga, kjer je med toponimi na obali okrog mesta naveden tudi rt po imenu Mića Baba, Vela Baba, Puntica.

Tem analizam je potrebno dodati vzorec, ki po svoji podobni strukturi potrjuje, da gre pri manjši mitski pokrajini okrog Peruna in Trebišć za ponovljajoč vzorčen pojav slovanske mitske krajine. Po vzorcu toponimov je namreč zelo podobna mitska krajina okrog Števerjana/San Floriano del Collio na Goriškem v Italiji, kjer se lahko sluti celo kombinacijo obeh tipov mitskih toponimov, tako rodiških kot trebiških. Slovanske mitske krajine so sicer razprostranjene povsod (Belaj in Belaj 2014; Pleterski 2014; Belaj idr. 2018; Čausidis 2008 itd.), vendar gre pri teh dveh za veliko primerljivost, ki lahko potrjuje podobna mitska ozadja.

V Števerjanu imamo na eni strani slovanske mitske toponime, ki kažejo na podoben vzorec kot pri Trebišćih - Trebežišče in nad njim hrib Kresavnik (Klemše idr. 1999; Hrobat 2010a, 217), pri čemer se Kresavnik v slovenskem izročilu pogosto pojavlja kot oblika Gromovnika, ki kreše z ognjem, kamnom (Mikhailov 2002; Kropej 2008, 58-75; Šmitek 2004, 139-178; Pleterski 2014, 100-101; prim. Čok 2012, 38), ${ }^{7}$ kar lahko primerjamo z goro

${ }^{7}$ Zmago Šmitek je ekstatičnega kresnika iz slovenskega in hrvaškega pripovednega izročila 
Perun in Trebišći pod njim na Hrvaškem; prav tako je v obeh mitskih krajinah prisoten toponim Babin grob. Podatek Radoslava Katičića $(2008,307)$, da se v cerkvenih spisih pogosto pojavlja kombinacija Peruna in njegovega trebišća, se tako potrjuje tudi v dveh konkretnih mitskih vzorcih v krajini. Da gre resnično za ponavljajoč se vzorec, nakazuje tudi podobna mitska toponomastika drugod s Hrvaške, recimo, kraj z izvirom po imenu Tribišče v mitski krajini Žrnovnice, od koder je lep pogled na cerkev sv. Juraja na Perunu, ali trikotnik s kotom $23^{\circ} 27^{\prime}$ med mitskimi točkami Trebovec, Veleševec in Sv. Martin v Prozorju ter številni drugi primeri toponimov, ki izhajajo iz besede treba in glede na mitske točke $\mathrm{v}$ okolici dokazujejo, da imena teh mest ne izhajajo iz »trebiti« kot fevdalnega krčenja zemljišč (Belaj in Belaj 2014, 187, 241-244, 430).

V mitski krajini Števerjana pozornost pritegnejo tudi tisti mitski toponimi, ki spominjajo na pripovedno izročilo Rodika: V sveti meji, Čuklja in dve Počivali (Klemše idr. 1999; Hrobat 2010a, 217). Podobno je v rodiški krajini Križen drev kot počivalo, ${ }^{8}$ Čuk, znotraj katerega naj bi domoval lintver in kjer se domneva predkrščansko kultno mesto, in meja, na kateri se osredotočajo izročila o "nadnaravnem«. Zanimivo, v Števerjanu ima meja pridevek "svetosti", medtem ko v rodiški krajini na to lastnost meje kaže pripovedno izročilo o srenjski meji, kar bo pokazano v nadaljevanju. Ob tem se velja spomniti na opažanje geografa Gregorja Kovačiča (2021), da je moral imeti Čuk nad Rodikom nek poseben pomen za človeka že glede na to, da mu je bilo dodeljeno ime, dokumentirano $\mathrm{v}$ najstarejših kartografskih gradivih, pri čemer nikakor ne izstopa po svoji geomorfološki obliki, saj komajda izstopa iz reliefa. Geografsko opažanje o kulturnem pomenu potrjuje moje domneve o nekem mitskem pomenu krajev, ki izvirajo iz besede Čuk, saj se pogosto pojavljajo v krajinah z mitskimi toponimi. Že samo rodiška krajina s Čukom in števerjanska s Čukljo nakazujeta na neke mitske simbolne pomene krajev, ki izhajajo iz besede Čuk.

sicer primerjal s šamanizmom in Ginzburgovimi benandanti iz furlanskega izročila (Ginzburg 1966; Šmitek 2015; 2019, 299-347).

${ }^{8}$ Potrebno je poudariti, da mi je Križen drev kot »mrtvo počivalo«, to je obredno mesto na pogrebni poti (Hrobat 2010b), pokazal samo pokojni domačin Rado Lukovec. Slišal je, da so se na tem mestu ustavili in zmolili s pogrebno procesijo na stari poti iz Artviž v Gročano. Na tem mestu naj bi stal zimzelen hrast, v katerega so bili vrezani križi. Koliko je to izročilo verodostojno, ne morem presoditi. Zanimivo je, da ga pred objavo knjige, v kateri pišem o "mrtvih počivalih", nisem slišala, zato se postavlja vprašanje kontaminacije izročila. Tudi Jasna Majda Peršolja o tem ni vedela ničesar. Sicer so na Križen drevu druga izročila, ki zaznamujejo mejo s strašljivim, glej v nadaljevanju. 


\section{Baba in njena umestitev $v$ mitski krajini}

Jasna primerjava z mitsko krajino okrog Trebišć je kamnit monolit na Rodiškem po imenu Baba (slika 2), ki je bila v dosedanjih raziskavah prepoznana kot ostanek najstarejše izpričanega ženskega (pra)slovanskega božanstva, Mokoš, vendar hkrati tudi neslovanskega mitskega lika v krajini. Naj povzamem nekaj ključnih ugotovitev, saj je bilo o babah že veliko napisanega. Babe kot kamniti monoliti ali deli pokrajine so na sploh povezani z mokroto, njihovi vzdevki pa z blatom, "šmrkavostjo « ali deževnim vremenom v slovanskem svetu ali Italiji (it. La vecchia). Pri tem je zanimivo, da je tudi slovanska boginja Mokoš povezana z mokroto, vlago, vodo, dnom. Na Krasu, v okolici Vipavske doline, v Istri in v Kvarneju so otroke strašili, da bodo morali ob prvem odhodu mimo kamnite Babe slednjo poljubiti, pihati v rit, odjesti njen »šmrkelj«, udariti s palico ipd., tako da je ta bajeslovni lik igral vlogo družbene kontrole; zaradi strahu, sploh pred Babo iz Trsta, so se otroci držali doma. V zvezi z babami so navadno zabeleženi tudi različni rituali, darovanja, opazovanja ob solsticiju, kot, recimo, na Golcu v Čičarji, na Velebitu ipd., Babja jama je bila na Posoškem v izročilu starovercev osrednja obredna točka v osrednjem tročanu. ${ }^{9} \mathrm{~V}$ slovanskem izročilu ima baba mnogo pomenov, od ženskega bitja in demona atmosferskih pojavov do povezav z različnimi nebesnimi telesi, zadnjim snopom žita, boleznimi, obrednim kruhom itd. Analiza njenih različnih besednih pomenov $\mathrm{v}$ slovenskem jeziku je pokazala na njeno dvojnost med rodovitnostjo in smrtjo: po eni strani označuje iztrošen, neploden vidik, po drugi strani pa ploden, temeljni, vitalen element s spolno močjo (npr. nosilni element $\mathrm{v}$ konstrukciji). Toponimi dele babinega telesa enačijo $\mathrm{z}$ elementi gora oziroma krajine (Babin nos, Babino koleno, glava, kolk, popek ...). Izročilo iz Krasa in Ligurije v severni Italiji govori, da ko pade otrok na tla, poljubi Babo. Baba torej ni nič drugega kot zemlja sama. V slovanskem svetu je Baba povsod interpretirana kot spomin na edino praslovansko žensko božanstvo, Mokoš, pri čemer pa primerjave presegajo zgolj slovanski svet. Podobna izročila o starkah, personificiranih v krajini, poznajo v Franciji kot La vieille ali v severni Italiji kot La vecchia, kjer ravno tako nastopa v groteskni otroški folklori o poljubu ob prvem mimohodu, kot zadnji snop žita in v napovedovanju deževnega vremena v po njej imenovanih hribih (Hrobat Virloget 2013; 2015; Hrobat 2010a, 183-226; Pleterski 2014; več v Belaj in Belaj 2014; Katičić 2011; Kropej 2008, 106-120; Toporov 2002, 42-53).

Veliko primerjav je bilo že nakazanih s folkloro v Franciji in Italiji (Hro-

${ }^{9} \mathrm{O}$ tročanih glej v nadaljevanju. 


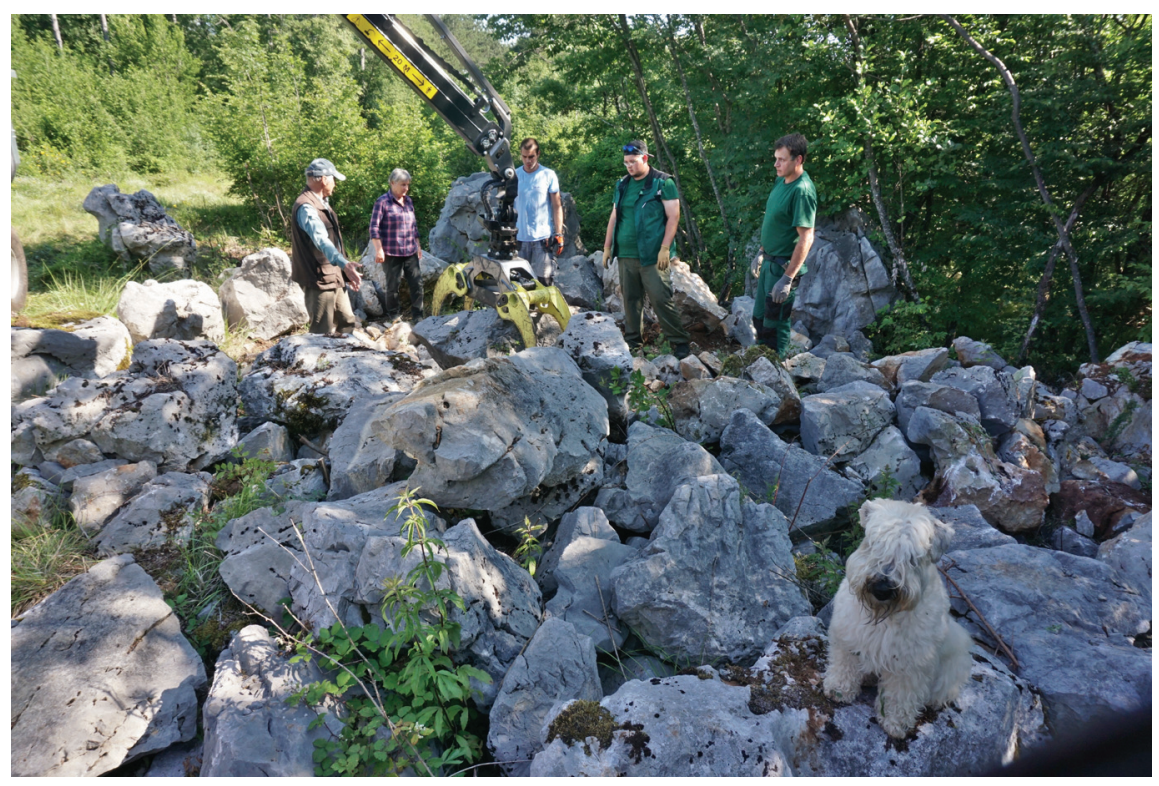

Slika 2 Razbitine razstreljene kamnite Babe ob urejanju v mandorlo kot simbol maternice življenja po umetniški interpretacije U N E S CO-vega umetnika za mir Marka Pogačnika (Pogačnik 2020, 95; avtorica fotografije Katja Hrobat Virloget)

bat 2010a, 183-226; Hrobat Virloget 2013; 2015), zato naj v tem prispevku dodam le nove primerjave s pripovednim izročilom iz Španije, ${ }^{10}$ ki tako potrjuje vsesplošno evropsko razširjenost lika starke oziroma babe. Pisala sem že o zelo podobnih pastirskih šegah, pri katerih so na Veliki Planini pred odhodom $v$ planine na pašo darovali kruh stari babi, da ne bi prinesla toče, na kar spominja šega iz doline Améscoa v Španiji, kjer so pastirji iz planin otrokom prinesli »kruh starke z gora" (Hrobat 2013, 155-156; Lapuente Martínez 1971, 116). Podobno izročilo o pan de Mari del monte v španščini ali »kruh Mari« $z$ gora je ravno tako v navarskem območju v dolini La Burunda. Izročila o »starki z gora « je mogoče najti tudi severneje v Španiji v pokrajinah León in Asturija, kjer otrokom prenaša kruh prek njihovih očetov, ki se vračajo $z$ dela na polju. Podobno kot v slovanski folklori mavrico tu imenujejo arco de la vieja ali cinturón de la vieja v pomenu loka ali pasu starke. Hkrati se pojavlja podobno kot predica in je povezana $\mathrm{z}$ luno, v Asturiji se pojavlja tudi v nekaterih jamah ali gorskih bivališčih. V jami La Cueva la Maruxina v okrožju Villamexín pri kraju Proaza so otroci

\footnotetext{
${ }^{10}$ Za primerjave v Španiji se zahvaljujem Nicolásu Bartoloméju Pérezu.
} 
na pustno nedeljo stekli do jame prosit starko za hrano (Bartolomé Pérez in Gancedo 2014; 2015; 2016). Vsa ta zelo podobna izročila namigujejo na to, da je bil mitski lik starke, pogosto povezan s krajino, zelo razširjen po Evropi, ne le v slovanskem svetu, temveč tudi v romanskem, kar skoraj gotovo nakazuje tudi arhaičnost tega vseevropskega izročila.

Žal pa starosti izročil ni mogoče datirati, prav pri babi pa je mogoče zaradi njenega materialnega vidika zaznati vsaj nekaj časovne globine $z$ okvirnimi datacijami. Najstarejša doslej znana monolitna Baba je namreč narisana kot kamnita kolona na meji med Tinjanom in Sv. Lovrečem v Istri na Hrvaškem, na meji med Beneško republiko in Avstrijo v notranjosti Istre, in sicer na zemljevidu iz 18. stoletja oziroma po originalu iz 16. stoletja (glej zemljevid v Panjek 2015, 124). ${ }^{11}$ Še starejši pisni dokaz o verovanju v Babo pa izhaja iz cerkve sv. Marije v Gračišću v hrvaškem delu Istre, kjer je na notranji omet cerkve vrisana figura debele ženske s pripisom Stara Baba Vukoša. Jelka Vince Palua domneva, da je nastala kot prošnja za rodovitnost neke ženske, ki je še $\mathrm{v}$ 15. stoletju ohranila staro vero in vrisala svojo prošnjo $\mathrm{v}$ še svež omet $\mathrm{v}$ votivni cerkvi device Marije, ki je pogosta krščanska zamenjava za Mokoš oziroma Babo (Vince Pallua 2018).

Opaziti je mogoče, da so kamnite babe kot pomembne simbolne točke $v$ prostoru tudi označevale katastrske meje. Kot je bilo pokazano zgoraj, se ena najstarejših kamnitih bab nahaja ne le na mejah katastrskih posesti, ampak tudi na (nekdanji) državni meji. Kot bo vidno v nadaljevanju, so bile meje v krajini posebnega simbolnega pomena, morda lahko rečemo celo svetega značaja (Hrobat 2010a, 66-67; Risteski 2005, 216-217; Guettel Cole 2004, 67-68, 77; Dragan 1999, 42-45, 93, 99, 101). Samo v okolici sta taka primera hrib in skala Železna babica na meji med Lokvijo in Povirjem na Krasu (Hrobat 2010a, 67) ali skala po imenu Baba na meji med katastrskima občinama Vrbovo in Jablanico, in sicer med naseljema Vrbovo in Vrbica $v$ bližini Ilirske Bistrice (Placer 2020, 216). Tudi ta Baba ima jasno krščansko preobleko z železnim krščanskim križem in dvema podobama sv. Marije (slika 3).

Gregor Kovačič me je opozoril, da je Baba na meji vrisana že v Franciscejskem katastru, pri čemer je pomenljivo ravno pod njo prečrtana beseda $\mathrm{Na}$ Divin. Raziskovalci so namreč opazili določeno pomensko zvezo v krajini med toponimi po imenu Baba in Deva. Domnevali so, da se za pogostimi

\footnotetext{
${ }^{11}$ Mejni kamen po imenu Baba med nekdanjima državnima ozemljema in hkrati katastrskimi območji še danes stoji (glej Bradara idr. 2017); za informacijo se zahvaljujem Aleksandru Panjeku.
} 


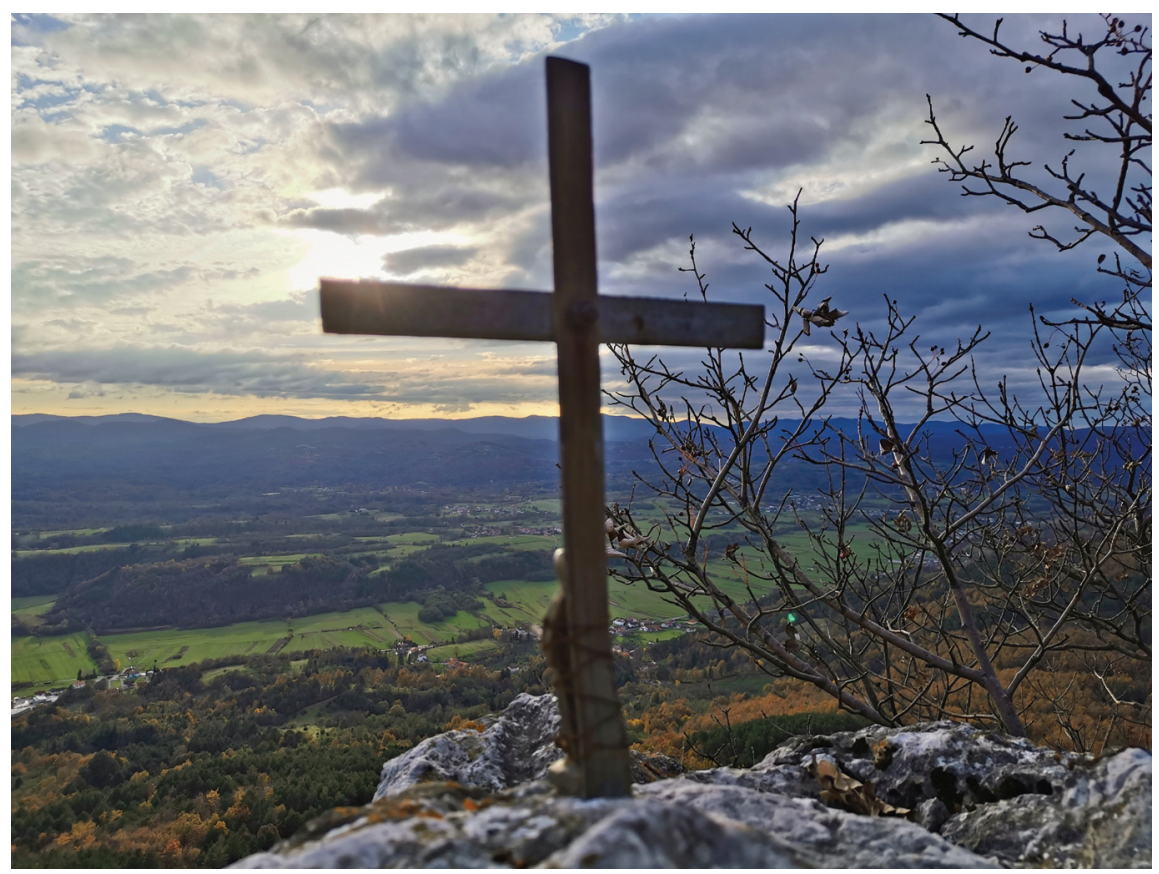

Slika 3 Baba z železnim križem in podobo Sv. Marija na meji med Vrbovim in Jablanico (avtorica fotografije Manica Radivo)

toponimi, ki izhajajo iz besede deva, skriva slovanska mitična zgodba. Zanimiv je grad Devin pri Trstu, kjer je v povedki prisoten motiv »devinega skoka«, pri čemer naj bi na dekle, ki je skočilo z gradu, danes spominjala kamnita Baba na pečini pod gradom (Beguš, Hrobat Virloget in Panjek 2015, 59). Zmago Šmitek toponim in povedko povezuje $\mathrm{z}$ mitično pripovedjo o tem, da je Perun kaznoval Mokoš zaradi njene nezvestobe (Peisker 1928, 1-36; Bezlaj 2003, 548-554; Šmitek 2008, 21-23; Placer 2020, 218-220; Toporov 2002, 49-52). Izpovedno je, da se oba toponima pogosto nahajata $\mathrm{v}$ neposredni bližini (Hrobat 2010a, 217-218). V Preložah pri Lokvi je Andrej Pleterski devo in babo interpretiral kot dva aspekta ženskega božanstva, vezana na zimski in poletni čas; v obredni jami Triglavci se pojavljata kot mitski plodnostni par Deva in Devač, njima so bile namenjene prošnje za rodovitnost, medtem ko v Preložah obstaja neplodnostni vidik v kamnih Baba in Dedec, kjer naj bi se po izročilu prišla pomirit zakonca po sporu (Pleterski 2015, 30-32). Mitski pomen omenjenih toponimov nadgrajuje raziskava Ladislava Placerja (2020), ki v pokrajini nad Ilirsko Bistrico prepoznava mitsko obredno pokrajino, v katerih sta dve mesti po imenu Devin in 
Mala ter Velika Milanja povezani z že omenjenim obrednim kotom, izven strukture pa se v neposredni bližini nahaja tudi zgoraj omenjena Baba nad Vrbovim in še en Devin.

Iz razporeditve $\mathrm{v}$ mitski krajini avtor sklepa, da so mesta po imenu Devin povezana s čaščenjem Mokoš, katere poletni in zimski vidik identificira $\mathrm{v}$ toponimih Milanja in Baba. Tudi v Rodiku je prisoten toponim, ki bi lahko izhajal iz imena Devin, to so Devce nad Pod lisičino, kjer je postavljena ena izmed mitskih točk zaradi izročila o divjanju mitske šembilje na tem mestu. V Franciscejskem katastru je to mesto najbrž mogoče prepoznati v ledini Douze pod Erbido, torej današnjo Robido, mitsko točko nad Pod lisičino (slika 4). Da bi lahko tudi v tem primeru šlo za neke mitske povezave, nakazuje ime potoka v neposredni bližini po imenu Zdrava voda. Voda iz Zdrave vode, ki je po besedah Jasne Majde Peršolja izvir, in voda iz Devc se zlivata v potok Sešica (Sušica?), ki teče mimo Pod lisičine. Že ime samo nakazuje, da naj bi imela po ljudskem izročilu neke zdravilne moči. To potrjuje tudi povedka, v kateri kragulj ozdravi odlomljeno roko fanta, ki je po Cikovi jami padel v oni svet (o pomenu jam v ljudskem izročilu glej Hrobat 2015), tako, da štrcelj roke ozdravi v potoku Zdrava voda (Peršolja 2000, 17).

Baba je morala $\mathrm{v}$ mitskem konceptualnem prostoru igrati eno temeljnih struktur, saj jo je kot element prostora še danes mogoče zaznati v mnogih vaških krajinah. Samo v zadnjih letih so me mnogi sogovorniki s Krasa in iz Brkinov obvestili, da imajo tudi na širšem območju njihove vasi kamen po imenu Baba, recimo v Slopah, na Barki, v Divači, Lokvi, Preložah, Gropadi na Tržaškem Krasu (Hrobat in Kavrečič 2015a, 79-80), in gotovo se bodo našli še drugi, ponekod so tudi jame ali drugi deli krajine. Če gledamo izročila, ki jih je pri t.i. starovercih zbral Pavel Medvešček, vidimo, da je baba pogosto nastopala kot del strukture tročana, pri čemer je lahko baba tudi gora, recimo Matajur kot Velika baba ali Vedrna baba (Medvešček 2015, 118, 377), ali jama, npr. Babja jama (Medvešček 2015, 330-332, 385386, 412-475), Duja Baba (Medvešček 2015, 333), Divja baba (Medvešček 2015, 337), ali kamnit monolit (Medvešček 2015, 384, 521) itd. Po ustnem izročilu tročan predstavlja verovanje $v$ tri naravne sile, ogenj (sonce), vodo in zemljo (Pleterski 2015, 16; Medvešček 2015, 114). Po enem izmed pripovedovanj je »tročan navidezna povezava treh točk v trikotniku. Povedano po domače je to verovanje $\mathrm{v}$ trojnost. Vse nevidne sile, ki so $\mathrm{v}$ tročanu potekale od ene do druge točke, pa so blagodejno vplivale na človeka, živali in rastline. Točka, ki povezuje dva ali več tročanov, pa je imela tudi čarno moč." (Medvešček 2015, 41) Znotraj tročana je tako govora o blagodejnih si- 


\section{Slika 4}

Ob večjem deževju priteče Pod lisičino potok, ki teče čez kolesnice, ki naj bi jih po izročilu v skali puščala šembilja, in se nahaja na stiku prehoda višje ležečih flišnih kamnin (peščenjak in laporovec) v nižje ležeči apnenec (avtorica fotografije Katja Hrobat Virloget)

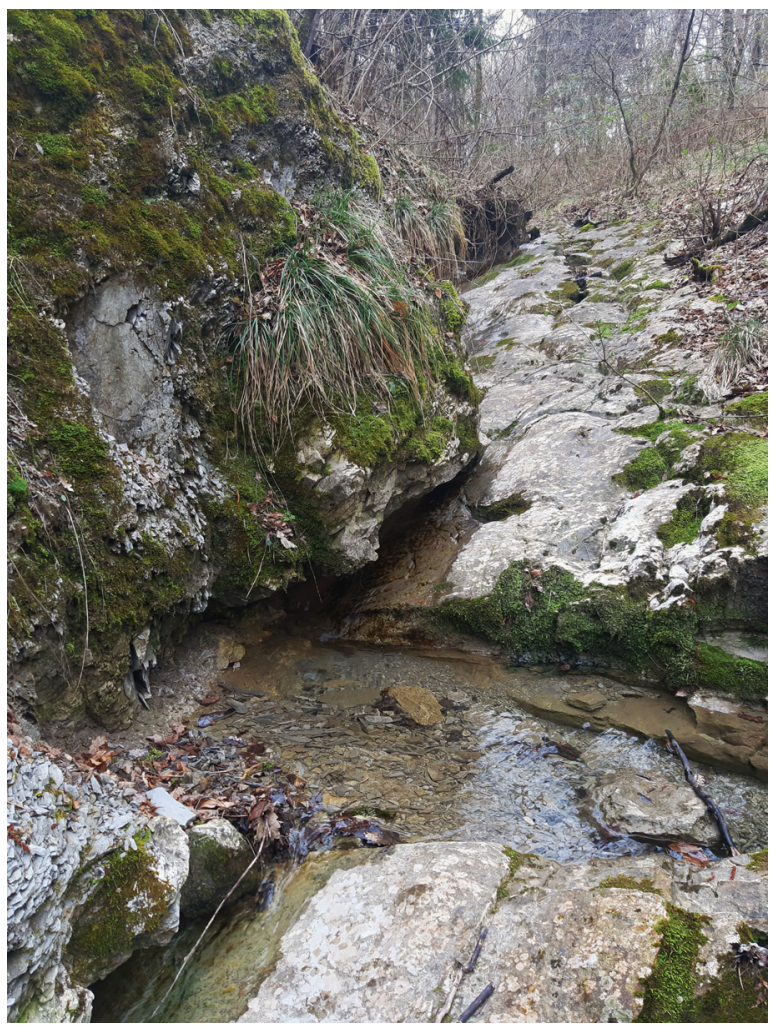

lah, za kar se striktno uporablja beseda "moč« in ne energija. Da so tročane staroverci povezovali z območjem blagodejnih moči, lahko sklepamo tudi iz pripovedi o tem, da se je njihov svečenik, dehnar, odločil znova vzpostaviti ravnovesje v prostoru tako, da naj bi tročane »očistil« negativne nesnage prve svetovne vojne, pri čemer sta mišljena tako človeško trpljenje oziroma bolečina kot vojna nesnaga v materialnem smislu (Medvešček 2015, 117). $\mathrm{V}$ teh širših krajinskih tročanih baba pogosto nastopa kot ena izmed treh temeljnih elementov, tako, recimo, naj bi bil na desnem bregu Soče tročan z dvema vrhovoma, Stolom in Gradom, ter Babjo jamo, in s Stolom, Kresnikom, ki zopet spominja na Gromovnikovo mesto, ter Babjo jamo, na levem bregu Soče pa so bili v tročan povezani Gošče, Mali vrh in Babja jama (Medvešček 2015, 41). Čeprav se po pripovedih sodeč Nikrmana zdi glavna božanska sila t.i. starovercev, je iz ene pripovedi, v kateri se je sogovornik nekoliko zapletel, razvidno, da je Velika Baba, enako kot Velika mati ali Nikrmana, morda le ime za ušesa neposvečenih (Pleterski 2015, 23; Medvešček 2015, 114). Baba oziroma žensko mitsko božanstvo je kot 
ena izmed treh točk dokazana tudi v raziskavah t.i. svetih trikotnikov $\mathrm{v}$ slovanski mitologiji, ravno tako trikotnih povezav med mesti treh mitskih likov, pogosto povezanih s t.i. svetim oziroma obrednim kotom (Pleterski 2014; Belaj in Belaj 2014). Pri tem bi lahko sklepali, da so se za trikotniki, ki so jih zaznali raziskovalci mitologije, skrivajo verovanja v podobne strukture, kot so tročani, o katerih izvemo iz »staroverskih« izročil (Pleterski 2015, 23-31; Hrobat 2019, 27).

Zanimivo je tudi opazovati, kako se toponimi in s tem tudi tisti mitski pomeni skozi čas spreminjajo. To je lepo vidno v Rodiku prav na primeru babe. Na zemljevidu iz 18. stoletja se namreč severozahodno od Rodika nahaja hrib po imenu Babina gora, ${ }^{12}$ ki verjetno danes ustreza hribu Gabrova stran s prazgodovinskim gradiščem (Medeot, Crevato in Margon 2021). O tem imenu danes $\mathrm{v}$ spominu Rodičanov ni več ne duha ne sluha, edina znana Baba je monolitna skala pod rodiškim poljem, ki je bila ob gradnji vodovoda leta 1989 razstreljena.

Tekom projekta Mitski park se je še enkrat pokazalo, da je izročilo spremenljivo in tudi različno interpretirano. Ko smo iskali točno lokacijo Babe, je prišlo do diskusij med Rodičani, kateri kamen je Baba. Krajina se je iz časa njihovega otroštva, ko so kot pastirčki ure preždeli na kamnu, povsem spremenila, tudi pogled nanjo je bil $v$ očeh otrok drugačen kot $s$ perspektive odraslih. Po spominu se je Baba namreč nahajala na najvišji vzpetini na gmajni, od koder je bil razgled na živino in pašnike okrog, medtem ko je danes ta krajina povsem poraščena in zaradi drevja ter grmičevja ni več nikakršnega širnega razgleda. Nekdo je tako zatrdil, da je Baba drug kamen v bližini trase vodovoda, ki deluje kot dolmen, a je po mnenju geografa Gregorja Kovačiča gotovo naravnega izvora. Vendar se je naposled večina sogovornikov vseeno strinjala in potrdila, da je Baba prvotno identificirana lokacija razstreljenega monolita ob vodovodni napeljavi (Hrobat 2010a, 186). ${ }^{13}$ Spomnim pa se, da je pokojni informator Rado Lukovec večkrat brezuspešno poskušal najti nek kamnit »dolmen«, kot je opisoval nenavadno kamnito strukturo, v bližini Babe, kar je verjetno bilo to. Avtorica objavljenega rodiškega pripovednega izročila Jasna Majda Peršolja se je na vprašanje o tem kamnu megleno spominjala, da se ji zdi, da so temu kamnu rekli Babec, ampak da ni bila pozorna nanj, ker ni bilo nobenega pripovednega izročila v zvezi z njim.

${ }^{12}$ Glej http://www.mapire.eu.

${ }^{13} \mathrm{Za}$ terensko delo z Rodičani tekom projekta in posredovanje informacij se zahvaljujem Valeriji Pučko iz Rodika. 


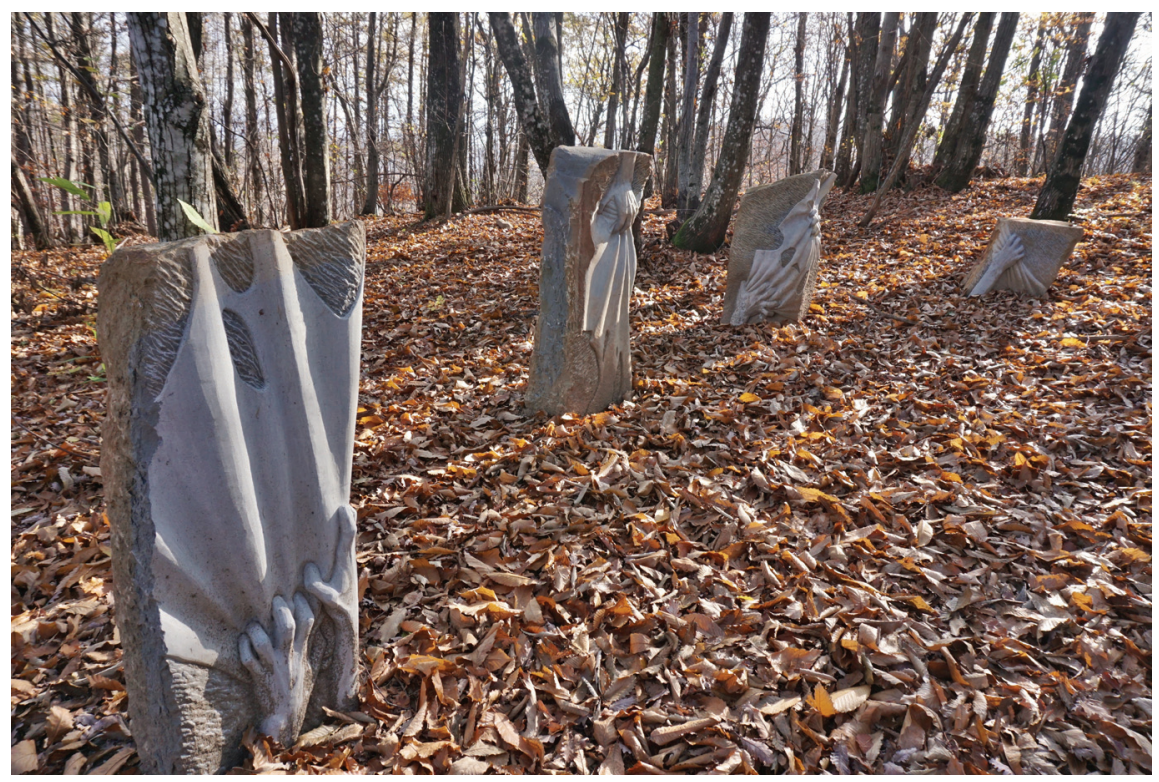

Slika 5 Skulpture na Kobilji glavi v avtorstvu Špele Šedivy, Sibile Leskovec in Ive Vite Hostnik, ki ponazarjajo zgodbo o tem, da so čarovnice na tem mestu raztrgale vedamca (avtorica fotografije Katja Hrobat Virloget)

\section{Katastrske meje v Rodiku in drugod}

Pet od dvanajstih postavljenih mitskih točk v Rodiku leži na ali v neposredni bližini vzhodne katastrske meje. Sicer so pripovedno izročilo in njegove interpretacije za vseh dvanajst izbranih točk iz Mitskega parka v Rodiku povzeti na drugem mestu (Hrobat Virloget 2020; Beguš, Hrobat Virloget in Panjek 2015, 67-79), vendar je potrebno opozoriti, da je vsaka točka veliko bogatejša s pripovednim izročilom (glej Peršolja 200o). Za namen turistične prezentacije smo ga bili namreč primorani osiromašiti, selekcionirati, saj smo morali izbrati le po eno povedko, vezano na določen kraj. Ko beremo iz knjige pripovednega izročila Rodika (Peršolja 200o), je tudi jasno, da je krajina pripovednega izročila veliko pestrejša in bogatejša, saj se ogromno povedk navezuje še na druga mesta, izbrane pa so bile le točke v bližini že obstoječih poti. Gotovo lahko med izpuščenimi pripovedmi izpostavim povedke o grofu Petaču, ki morda predstavljajo neko mlajšo fazo izročila $\mathrm{z}$ mitskimi vsebinami. V parku je samo enkrat prikazana njegova zgodba, in sicer na enigmatični ledini Kobilja glava, kjer naj bi volkovi raztrgali grofovo kobilo (Hrobat 2010a, 74; slika 5). Na tem mestu naj bi čarovnice raztrgale vedamca, bila naj bi kobilja lobanja na kolu, najden je 


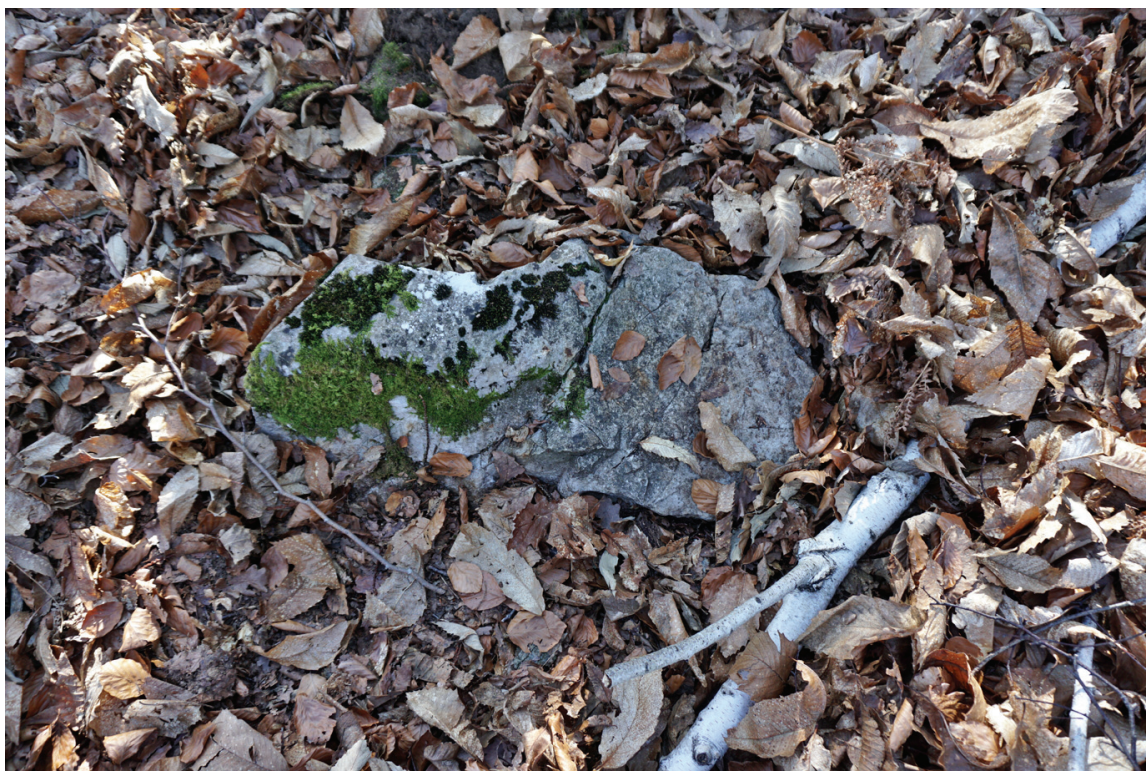

Slika 6 Apnenčasta skala v obliki konjske glave na Kobilji glavi, ki je po mnenju geografa Gregorja Kovačiča tujek na brkinskem slemenu iz peščenjaka in laporovca (avtorica fotografije Katja Hrobat Virloget)

bil tudi apnenčast kamen $\mathrm{v}$ obliki konjske glave (slika 6), pokopan naj bi bil dojenček, zaklad, skratka, v večini strašljiva izročila, povezana s smrtjo. Sicer je imel konj že v tradiciji poseben simbolni pomen, od njegove apotropejske vloge, povezave $\mathrm{z}$ božanskim do vloge psihopompa. Po slovanskih tradicijskih verovanjih naj bi konjska lobanja na kolih na ogradah ščitila pred vdori zla (Hrobat 2009a, 76-77, 214; Dragan 1999, 105). V slovanski mitologiji naj bi bila glavna mitska lika, Juraj in Mara, Perunova otroka in dvojčka, podobna konju, zato imena, ki izhajajo iz besede konj, Vitomir in Juraj Belaj pogosto interpretirata v kontekstu slovanske mitske pokrajine (Belaj 1998, 168-206; Belaj in Belaj 2014, 49, 107, 129, 167, 322). Zanimivo, tudi iz naslova drugačnega resničnostnega programa, geomantičnega, je Kobilja glava povezana $\mathrm{z}$ dušami mrtvih (Pogačnik 2020, 123). Da je moralo imeti ledinsko ime Kobilja glava poseben simbolni pomen, nakazujejo tudi druge sorodne raziskave mitske krajine, npr. o ledini Kobila z izročilom o zakopanih zakladih pri Sodražici (Češarek 2015) ali pri starovercih ledina Kobilja glava, ki naj bi bila po pripovedih »obremenjen« prostor, na katerega so se ravno tako kot v primeru Rodik navezovale strašljive pripovedi o strašenju, pokopih, grobovih starovercev itd. Zanimivo, 
ledina se nahaja pod zgoraj omenjenim sv. Jakobom oziroma nekdanjim predkrščanskim svetiščem Škeljak in po pripovedih naj bi bil tu tudi daritveni prostor (Medvešček 2015, 333).

Po umestitvi pripovednega rodiškega izročila v krajino se je pokazalo, da je Kobilja glava eno izmed številnih mest na katastrskih mejah, kot so Njivice, Križen drev, Robida, Pod lisičino, ki jih označuje stik z onstranskim. Na točkah ob meji se odpirajo prehodi v onstranstvo, videva se ogenj, v katerem se vicajo duše (Njivice, Prelovec), na mejah se dogajajo umori, razkosanje trupel bitij tega in onega sveta ter pokopi (Njivice, Prelovec, Križen drev, Kobilja glava), prikazujejo se nadnaravna bitja, kot sta krvavo stegno in šembilja, bitja, ki so povezana s posredovanjem med obema svetovoma, kot so kovač, čarovnice, vedamec itd. Razkosanje trupel na mejah in tromejah najbrž nakazuje simboliko žrtvovanj, ki jih lahko zasledimo tudi drugod po Evropi (Hrobat 2010a, 86-87; Dragan 1999, 42-65, 99; Kvideland 1993, 19). Kot ugotavlja zgodovinar Simon Young, kraji niso nujno vezani z neko specifično »nadnaravno" prikaznijo, ampak jih lahko označuje nek občutek splošne "nadnaravne« nevarnosti (Young 2020, 2). Hipotezo o označevanju katastrskih mej z "nadnaravnim«, s kraji, kjer straši, potrjuje njegova analiza umeščanja »nadnaravnega « v krajino 19. stoletja v Veliki Britaniji. Ugotavlja tri značilnosti krajevnega prikazovanja prikazni, kar so pokazale tudi moje raziskave (Hrobat 2009a; 2010a; Hrobat Virloget 2014): koncentrirajo se okrog naselij, na mejah, pogosto se nahajajo na strateških mestih - na križiščih, mejah, mostovih in ob rekah. Prikazni na splošno ne živijo znotraj človeške skupnosti, ampak v odnosu do njih (Young 2020, 15, 22). Te prikazni označujejo mejna območja, liminalna mesta v pokrajini, kjer »nadnaravno« vstopa v »naš« svet, svet živih. Tako mejna območja predstavljajo meje "našega sveta« $v$ funkcionalnem pomenu, to je kot meje vasi s sosednjo, kot tudi v kozmološkem smislu kot meja med "svetom živih" in onstranskim (Hrobat 2010a, 62-106, 180-182; 2009a; 2009b, 349; Hrobat Virloget 2014). Če jemljemo sveto v prostorskem pomenu, kot ga Radu Dragan (1999, 62) uporablja za označevanje onstranskega ali francosko altérité, »drugost « ${ }^{14}$ bi lahko meje pojmovali kot svete. $\mathrm{V}$ teh liminalnih območjih pomeni prekinitev $\mathrm{z}$ mejo vstop $\mathrm{v}$ alternativno resničnost oziroma se s prestopom iz enega ozemlja v drugo človek v materialnem in magično-religioznem smislu znajde med dvema svetovoma (Harte 1994, 6; Van Gennep 1909 [1981], 24; Young 2020, 15). Kot je bilo

\footnotetext{
${ }^{14}$ Termin "sveto je bil sicer vpeljan v 19. stoletju v »znanost o religiji« iz potrebe po novem pojmu, ki bi obsegal vse fenomene (glej Kravanja 2007, 49-64).
} 
že pokazano, se folklorni vidik meja kot posebnih razmejitvenih prostorov $\mathrm{v}$ kozmološkem pomenu nadgrajuje $\mathrm{z}$ ritualnimi dejavnostmi. Na meje se namreč vežejo tudi posebne ritualne aktivnosti, kot so, recimo, mrtva počivala, mesta obrednega postanka s pokojnikom v pogrebni procesiji prav na katastrskih mejah, ali tudi druge ritualne dejavnosti skozi čas, od rednih obrednih letnih obhodov in obnavljanj vaških mej v Sloveniji in drugod do čaščenja mejnih božanstev (lat. Terminus) v antiki, sankcij za prestop in premik meje, postavljanja svetih točk nanje, zakopavanja predmetov itd. (Hrobat 2010a, 107-188, 278-279; Hrobat 2009b).

\section{Smernice in problemi pri ohranjanju pripovednega izročila v Mitskem parku}

Ob koncu novih spoznanj o mitski krajini Rodika in Trebišć, ki sta v projektu Mitskega parka poenotena v enotno turistično destinacijo, naj nakažem še nekaj smernic in problemov pri upravljanju parka, ki temelji na nesnovni dediščini (Čebron Lipovec 2021). Pri nesnovni dediščini pripovednega izročila v parku je glavni problem to, da smo jo na eni strani rešili iz pozabe in umiranja, vendar smo jo za potrebe turistične predstavitve "zamrznili« v obliko sodobnih avdiovizualnih posnetkov, kamnitih skulptur in zapisov ( $v$ knjigi in na razstavi v Sprejemnem centru v Rodiku). Ob tem se zavedamo, da so glavne značilnosti nesnovne dediščine ravno nasprotne od tega, kar si predstavljamo kot »avtentično«, torej nekaj »fiksnega, sukoreninjenega $\mathrm{v}$ času in prostoru, saj nesnovno dediščino označujejo spremenljivost skozi čas, kreativnost, domišljija, izvedba, ki ni nikoli enaka“ (Scounti 2009; Hrobat 2019, 34). Pri tem se zastavlja vprašanje, ali je v svoji »okameneli« obliki (selekcionirano) pripovedno izročilo Rodika še vedno nesnovna dediščina? Odgovor bomo verjetno dobili šele v bodoče, ko bo postalo jasno, $v$ kakšne smeri se bo park oziroma njegovo pripovedno izročilo razvijalo. Na tem mestu podajam nekaj smernic za upravljanje $z$ nesnovno dediščino $v$ parku, ki naj bi pomagale pri tem, da bi nesnovna dediščina pripovednega izročila tam kljub svoji »zamrznitvi« še vedno živela.

Najpomembnejši in skupni napotek vsem ciljnim skupinam, ki bodo pri svoji dejavnosti uporabljale pripovedno oziroma mitsko izročilo, je, naj se pripovedno izročilo ne banalizira, še posebej znotraj procesov poblagovljenja (Čebron Lipovec 2021). Pri pregledu uporabe ali celo zlorabe pripovednega izročila v javnosti je namreč opazno, da so mitske vsebine dandanes prepogosto banalizirane. Prav zato v tem projektu skušamo slediti dejstvom, ki bodo čim bližje temu, kar je o preteklosti znano na strokovni ravni. Zelo pogosto se namreč zlorablja predstave o nekih namišljenih ro- 
mantičnih prednikih (recimo za fotografije, videe, gledališke skupine, oblačila, nakit...), ki nimajo nikakršne znanstvene podlage. Podobe prednikov, ki jih navadno take rekonstrukcije predstavljajo, so podobnejše "new age« reinterpretacijam, kjer so predniki predstavljeni v vlogi nekakšnih "surovih, pogosto poslikanih divjakov«, ki so ravno stopili iz divjine, kar je mogoče videti tudi v igranih prizorih slovanske mitologije $\mathrm{v}$ Trebišćih. Tega si v strokovno osnovanem Mitskem parku ne smemo dovoliti. Ljudje so bili stoletja in tisočletja pred nami enaki današnjim ljudem, morda so res imeli drugačne obleke, drugačne posode, ampak obnašali so se, čustvovali in živeli podobno kot mi danes ... Medtem ko se ima današnji tehnični človek za razvitejšega, lahko predpostavljamo, da so bili nekoč na področjih, ki ne zadevajo tehničnosti, temveč zaznavanje ali podobno, razvitejši naši predniki. Obiskovalcu moramo v parku dati občutek, da gleda samega sebe, svoje prednike, edina razlika med nami je $\mathrm{v}$ tem, da smo različno zaznavali svet - eni danes verjamejo v Kristusa ali znanost, eni so v Peruna in Babo, eni dvomijo in so dvomili v vse ... To prvo opozorilo velja predvsem turističnim operaterjem in ponudnikom, ki prepogosto zapadejo $\mathrm{v}$ t. i. »uprizorjeno avtentičnost « (Poljak Istenič 2013, 106) oz. "ponarejanje«: izdelovanje domnevnih replik oblek, ki naj bi jih nosili nekoč; izdelovanje kičastih spominkov ali uvajanje povsem novih festivalov in dogodkov, ki izročilo spojijo v novo in preveč popreproščeno obliko, katere cilj je zgolj dobičkonosni »show", ne pa zavedanje in spoštovanje dediščine in narave, ki vodita v trajnostno sobivanje. Obratno pa lahko prav odkrivanje te dediščine posebej lokalnemu prebivalstvu odpre nove možnosti za kreativnost in ustvarjanje novih produktov, ki črpajo iz izročila, a so produkt sodobnega časa. Ob tem je pomembno to, da se tudi po vzpostavitvi Mitskega parka ohranja strokovni nadzor nad njegovimi vsebinami v prihodnosti. Medtem ko se pri Rodiku prisotnost stroke zdi logična tudi v bodoče, saj je bil park ustvarjen prav v tesnem sodelovanju med stroko in lokalno skupnostjo (Hrobat Virloget 2019, 33-35), se pri Trebišćih to zdi bolj vprašljivo, saj v bližini ne deluje noben strokovnjak s področja mitologije, ki bi še po postavitvi parka imel dovolj avtoritete pri lokalni skupnosti. S tega stališča se postavlja tudi vprašanje, koliko demokratičnosti lahko stroka dopusti različnim laičnim interpretacijam, da te ne zaidejo na stranpoti, kot je žal pogosto prav pri mitskih vsebinah (glej Hrobat Virloget 2019).

Že v času projekta sem bila sama priča mnogim izkrivljenim interpretacijam, ki so izhajale predvsem iz laičnih interpretacij mitskega izročila. Že samo ime parka je za nestrokovnjake pogosto zavajajoče, saj na njegovi podlagi večina ljudi pričakuje, da bo govora o mitih. Vendar je na področju 
folkloristike znano, da v Evropi ni ohranjenega niti enega samega mitskega teksta, sploh takega, ki bi imel sveti obredni kontekst. Kar pa se je ohranilo, je mitsko izročilo, to so drobci nekih mitskih verovanj, ki jih najdemo v različnih šegah in navadah, toponimih, pripovednih izročilih, zapisih itd. (Belaj 1998; Mikhailov 2002). Na ime parka sem kot strokovnjakinja pristala bolj zaradi rekonstrukcije (pra)slovanske mitologije $\mathrm{v}$ Trebišćih, medtem ko imamo v Rodiku opraviti zgolj z mitskim izročilom, ki se kaže v posameznih mitskih bitjih (npr. šembilja, lintver, Baba itd.) ali kultnih mestih. Največjo bitko sem tako tekom trajanja projekta morala voditi proti uporabi besede mit, saj so tako partnerji kot novinarji pogosto govorili, da bomo v Mitskem parku spoznavali mite (npr. Race 2020) - v Rodiku zagotovo ne, v Trebišćih pa zgolj eno izmed rekonstrukcij slovanske mitologije. Tako sem kot strokovnjakinja popustila pri senzacionalističnem imenu parka, ki naj bi bil atraktivnejši za širšo javnost, kar pa bo v bodoče predstavljalo problem za stroko, če bo (v njeni odsotnosti) namesto o pripovednem izročilu zopet govora o mitih.

Drugi poudarek projekta je krajina, prostor! Vse pripovedi, vsi toponimi v parku so se ohranili zato, ker se »lepijo« na krajino, prostor. Zgodbe in toponimi pojasnjujejo krajino, nekdanje človekovo dojemanje prostora in njegovo umestitev v nekdanji kozmološki svet. Medtem ko danes v pojasnjevanju krajine prevladuje znanstveno-tehnični diskurz, je nekoč prevladoval drugačen pogled na svet, ki ga danes zasledimo v pripovednem izročilu. Pri vsakršnem predajanju ustnega izročila je potrebno imeti v mislih, da govorimo o (trajnostnem in sonaravnem) načinu sobivanja ljudi z naravo oziroma $\mathrm{z}$ okoljem, $\mathrm{v}$ katerem je človek živel. Enakovredno pozornost naj se posveča tako vidikom kulturne dediščine kot tudi naravnim vrednotam, pri čemer velja poudariti tudi prakse sonaravnega načina bivanja (npr. gradnja suhozidov, upravljanje gozdov, srenjske zemlje ...) (Hrobat Virloget in Čebron Lipovec 2020).

Tretji poudarek projekta je pripovedovanje ustnega izročila. Do danes so se nam ohranili mitski toponimi in pripovedno izročilo, na osnovi česar je bil park postavljen. Vendar če park ostane zamrznjen $v$ tej obliki prezentacije, če bodo pripovedi obstale le še v kamnu in če bodo izumrle $v$ življenju ljudi, če se ljudsko izročilo ne bo pripovedovalo naslednjim rodovom in obiskovalcem, bo park izgubil smisel. Smisel je v prenosu nesnovne dediščine na bodoče generacije. Ne smemo pozabiti tudi, da prenos nesnovne dediščine pomeni tudi spreminjanje, saj se nesnovna dediščina nikoli ne izvede na isti način in se ves čas prilagaja. Pomembna je zatorej tudi ustvarjalnost. Teme iz Mitskega parka se lahko preoblikujejo v različne raziskovalne in 


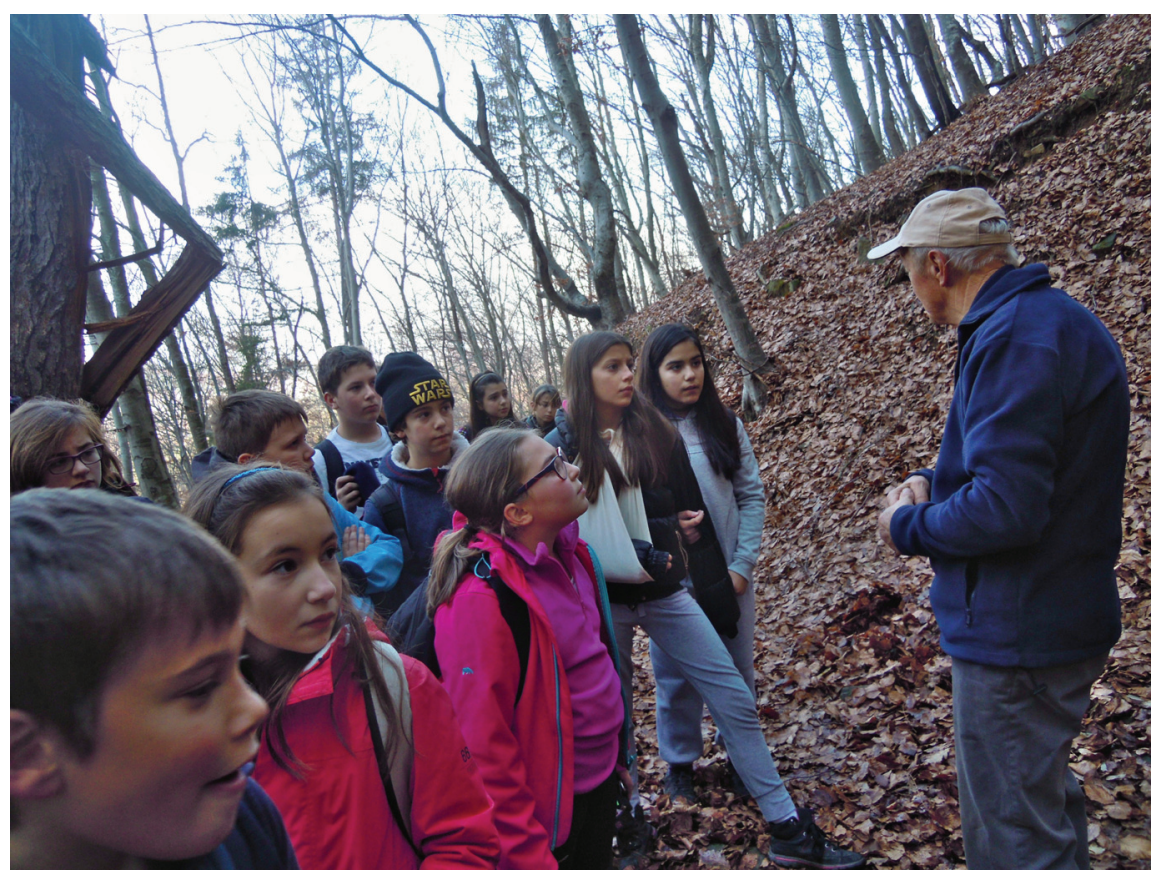

Slika 7 Pokojni informator Lado Lukovec ob pripovedovanju zgodb učencem italijanske šole Pier Paolo Vergerio iz Kopra. Lado Lukovec me je kot strokovnjakinjo vodil po terenu in na osnovi njegovega poznavanja krajine smo vzpostavili Mitski park. Da bi Mitski park zares (za)živel, bi morali turistični vodniki in lokalni prebivalci tudi sami doživeto pripovedovati zgodbe na terenu.

ustvarjalne dejavnosti, kot so zbiranje spominov starih staršev, raziskovanje doslej nepoznanega pripovednega izročila, učenje t.i. storytellinga od strokovnjakov itd. Da bi pripovedno izročilo (o)živelo, smo v parku izobrazili turistične vodnike, katerih naloga je poleg interpretacije povedati zgodbo določenega kraja na zanimiv način, v stilu t. i. storytellinga (slika 7).

Četrti poudarek, ki ni zgolj poudarek projekta, temveč celotnega razpisa, je čezmejnost, preseganje nacionalnih meja in nacionalizmov. Zavedati se moramo, da so narodi nov pojav v zgodovini, star komajda dve stoletji, zato starodavnih mitskih predstav nikakor ne moremo povezovati s sodobnimi nacionalnimi skupinami, recimo Slovenci ali Hrvati. Takrat jih namreč ni bilo oziroma vsaj ne v taki obliki, kot si jih »zamišljamo« danes (Anderson 2007). Žal se iz napisov na starejših informacijskih tablah v Trebišćih večkrat sluti nacionalistično ideologijo oziroma povezovanje Slovanov in slovanske mitologije s sodobno hrvaško nacionalno identiteto. Danes taka 
namigovanja veljajo za strokovno sporna; če pogledamo zgodovinski kontekst postavitve tabel, sprevidimo, da je do tega prišlo ravno $\mathrm{v}$ času osamosvajanja hrvaškega naroda. ${ }^{15}$ Danes lahko govorimo o širših temah, kot so različna zaznavanja sveta, o rekonstrukciji (pra)slovanske mitologije in različnih hipotezah itd. Izogibati pa se moramo povezovanju (slovanske) mitologije s sodobnimi nacionalnimi identitetami, kar je, recimo, vse pogostejši problem sodobnih verskih gibanjih, kot recimo teh, ki se navezujejo na tradicijo ti. "staroverstva«. Zato mora biti stroka še toliko bolj kritična in angažirana pri dekonstrukciji političnega mita (glej Hrobat Virloget 2019; Rihtman Avguštin 2001, 210).

\section{Zaključne misli in vprašanja}

Po Ulrichu Kocklu (2007) tradicija postane dediščina, ko se ne več uporablja v našem vsakodnevnem življenju, se ne prenaša in se uporablja zven izvornega konteksta. V Rodiku je bilo pripovedno izročilo na poti v izumrtje rešeno prav z Mitskim parkom, pri čemer je prišlo do prenosa na druge, sodobne oblike prenosa $\mathrm{v}$ obliki avdio-vizualnega gradiva. Izvorni kontekst se je tako umaknil sodobni tehnologiji. Od tu izhaja glavni izziv parka z vprašanjem, kako danes ponovno oživeti lokalno pripovedno izročilo, da bo vsebovalo vse značilnosti nesnovne dediščine, kot so spremenljivost, variabilnost, kreativnost? Ali lahko dediščina spet postane (vsakdanja) tradicija, pa čeprav v drugih oblikah in z drugačno publiko?

Pri Mitskem parku je stroka skupaj z lokalno skupnostjo ustvarila dediščino »od zgoraj navzdol« kot odgovor na sodobno iskanje unikatnosti, "avtentičnih" (pred-krščanskih) tradicij, h katerim se sodobna družba tako pogosto zateka (primer ti. »starovercev«), kot odgovor na preoblikovanje kolektivne identitete, zakoreninjene v lokalnih specifikah prostora in časa, ter kot odgovor na sodobne potrebe po prepoznavnosti, zelenem in dediščinskem turizmu (Hrobat Virloget 2019). Po koncu projekta bo ta predan v upravljanje lokalni skupnosti, občini Hrpelje-Kozina, v sodelovanju s Krajevno skupnostjo in Turističnim društvom Rodik. Pomembno pri tem je vprašanje, koliko bo stroka v bodoče ohranila nadzor nad vsebinami parka.

Čisto za konec naj podam svojo subjektivno misel kot strokovnjakinja, ki je na osnovi dolgoletnega raziskovanja zasnovala vsebine Mitskega parka v Rodiku od prve ideje (Hrobat Viroget 2011) do idejne zasnove v projektu Li-

${ }^{15}$ Zahvaljujem se prof. dr. Marijani Belaj iz Oddelka za etnologijo in kulturno antropologijo Filozofske fakultete Univerze v Zagrebu, ki me je opozorila na zgodovinski kontekst. 
ving Landscape ${ }^{16}$ (Beguš, Hrobat Virloget in Panjek 2015; Hrobat Virloget in Kavrečič 2015b) in realizacije v okviru Mitskega parka. ${ }^{17}$ Že na drugem mestu sem razmišljala o vlogi stroke pri prepoznavanju dediščine in posledično o njenem vplivu na izumljanje tradicij (Hrobat Virloget 2010a). Kot etnologinja, postavljena v aplikativno delovanje, namreč že vrsto let spremljam, kako se dediščina »iz mojih rok« spreminja in prilagaja širši javnosti (npr. selekcija pripovednih izročil, selekcija točk izročila v krajini ...). Tudi ob poslušanju pripovedi lokalnih turističnih vodnikov sem opustila upanje, da bodo moje strokovne interpretacije podane naprej točno tako, kot sem si zamislila. Ob koncu postavitve Mitskega parka si tako postavljam dve temeljni vprašanji. Kako se bo nesnovna dediščina spremenila $\mathrm{z}$ intervencijo turizma in etnologije? In bistveno, ali bo lokalno pripovedno izročilo preživelo zgolj v svoji »okameneli« obliki ali bo znova oživelo v svoji kreativnosti? Pustimo času naj pokaže uspešnost tega velikega skupnega izziva, rojenega iz sodelovanja stroke in lokalne skupnosti.

\section{Literatura}

Anderson, B. 2007. Zamišljene skupnosti: o izvoru in širjenju nacionalizma. Ljubljana: Studia Humanitatis.

Bartolomé Pérez, N., in E. Gancedo. 2014. »La vieja del montes: La bruja buena de los montes leoneses. «Diario de León, 12. januar. https://www .diariodeleon.es/articulo/revista/bruja-buena-montes-leoneses/ 201401121227001404439.html.

— 2015. »La vieja del monte I: A casa da Tía Prieta.« Diario de León, 27. december. https://www.diariodeleon.es/articulo/revista/a-casa-da-tia -prieta/201512270400011563837.html.

— 2016. »La vieja del monte III: Mitos hermanos.« Diario de León, 10. januar. https://www.diariodeleon.es/articulo/revista/mitos-hermanos /201601100400021566541.html.

Beguš, I., K. Hrobat Virloget in A. Panjek. 2015. Med kamenjem: snovna in nesnovna krajina Krasa. Trst: Pokrajina Trst.

Belaj, V. 1998. Hod kroz godinu: mitska pozadina hrvatskih narodnih običaja $i$ vjerovanja. Zagreb: Golden marketing.

Belaj, V., in B. Belaj. 2014. Sveti trokuti: topografija hrvatske mitologije. Zagreb: Matica hrvatska.

Belaj, J., M. Belaj M., S. Krznar, T. Sekelj Ivančan in T. Tkalčec, ur. 2018.

\footnotetext{
${ }^{16}$ Program čezmejnega sodelovanja Slovenija-Italija 2007-2013 iz sredstev Evropskega sklada za regionalni razvoj in nacionalnih sredstev, vodja Aleksander Panjek, U P F H Š.

${ }^{17}$ Program sodelovanja Interreg V-A Slovenija-Hrvaška 2014-2020. Projekt je sofinanciran iz sredstev E S S R. Vodja Občina Hrpelje-Kozina.
} 
Sacralization of Landscape and Sacred Places. Zagreb: Institute of Archaeology Zagreb.

Bezlaj, F. 2003. "Problematika imen Vir in Skočidjevojka."V Zbrani jezikoslovni spisi 1, ur. M. Furlan, 548-555. Zbirka Linguistica et philologica. Ljubljana: Založba Z RC.

Bilić, T. 2020. "Mit o ssvetim trokutima temeljenima na ssunčevom kutu< analiza rastronomije ranih Slavena." Studia mythologica Slavica 23:3550.

Bradara, T., M. Joksimović, J. Šipoš, E. Barbalich-Geromella, K. RadošPerković, B. Budicin in D. Juričić Čargo. 2017. Mletačko-austrijska granica u Istri/Il confine veneto-austriaco in Istria. Pulj: Arheološki muzej Istre/Museo archeologico dell'Istria.

Čausidis, N. 2008. "Mythologization of the Mountain (A Diachronic Survey of Examples from Macedonia and the Wider Balkan region).«V Memory \& Art: Interpretations, ur. K. Kulavkova, 2:261-303. Skopje: M A N U.

Čebron Lipovec, N. 2021. »Poskus orisa izzivov v upravljanju Mitskega parka v Rodiku.«V Mitska krajina: iz različnih perspektiv, ur. K. Hrobat Virloget, 147-175. Koper: Založba Univerze na Primorskem.

Češarek, D. 2015. »Izročilo o psoglavcih, volkodlakih, volčjem pastirju in Atili v mitski krajini Sodražice."Studia mythologica Slavica 18:131-152.

Čok, B., 2012. V siju mesečine: ustno izročilo Lokve, Prelož in bližnje okolice. Studia Mythologica Slavica: Supplementa 5. Ljubljana: Založba Z RC.

- 2015. "Kamnoseško izročilo o znamenjih na portalih in kolonah po Krasu. "V Nesnovna krajina Krasa, ur. K. Hrobat Virloget in P. Kavrečič, 99-134. Koper: Založba Univerze na Primorskem.

Dragan, R., 1999. La répresentation de l'espace de la société traditionnelle: les mondes renversés. Pariz: L'Harmattan.

Ginzburg, C. 1966. I benandanti: stregoneria e culti agrari tra Cinnquecento e Seicento. Torino: Einaudi.

Guettel Cole, S., 2004. Landscapes, Gender, and Ritual Space: The Ancient Greek Experience. Berkeley, c A: University of California Press.

Halbwachs, M. 1971. La topographie légendaire des évangelis en terre sainte: etude de mémoire collective. Pariz: Presses Universitaires de France.

- 2001. Kolektivni spomin. Ljubljana: Studia Humanitatis.

Harte, J. 1994. »Haunted Lanes. « The Ley Hunter 121:1-7.

Harvey, D. C. 2001. »Heritage Pasts and Heritage Presents: Temporality, Meaning and the Scope of Heritage Studies. «International Journal of Heritage Studies 7 (4): 319-338.

Hrobat, K. 2004. „Ustno izročilo o lintverju kot indikator ritualnega prostora antične skupnosti Ajdovščine nad Rodikom.« Studia mythologica Slavica 7:63-78.

—. 2009a. »Folklora v vlogi označevanja vaških mej kot prostorskih vr- 
zeli v onostranstvo: primer Rodika.« Studia mythologica Slavica 12:207222.

2009b. »Percepcija prostora skozi folkloro: ımrtva počivala in voda v vlogi meje z onostranstvom na Krasu.«Annales: Series historia et sociologia 19 (2): 341-352.

- 2010a. Ko Baba dvigne krilo: prostor in čas v folklori Krasa. Zbirka Razprave. Ljubljana: Znanstvena Založba Filozofske fakultete.

- 2010b. "Prostorska struktura vasi v ustnem izročilu, šegah in navadah na Krasu.« Traditiones: zbornik Inštituta za slovensko narodopisje 39 (2): 87-105.

Hrobat Virloget, K. 2011. "Mitično-arheološki parki: predlog kakovostnega dediščinskega turizma."V Uporaba prostorov: strokovni zbornik, ur. S. Klaus in A. Kvartič, 7-12. Ljubljana: Znanstvena založba Filozofske fakultete.

- 2013. „The Snooty Baba in the Landscape of Karst, Slovenia: About a Slavic Ambivalent Female Mythical Figure. Cosmos: The Yearbook of the Traditional Cosmology Society 29:141-171.

- 2014. „Conceptualization of Space through Folklore: On the Mythical and Ritual Significance of Community Limits. "V Archaeological Imaginations of Religion, ur. T. Meier, 359-382. Budimpešta: Archaeolingua Alapítvány.

- 2015. "Mythical Tradition in the Stone: The Snooty Babas as Elements of Rites of Passage and Social Control."V Stone Narratives: Heritage, Mobility, Performance, ur. K. Hrobat Virloget in I. Weber, 55-64. Koper: Založba Univerze na Primorskem.

- 2019. "O aktivni in pasivni vlogi stroke ter javnosti pri ustvarjanju nesnovne dediščine: primer mitskega parka in starovercev."V Nesnovna dediščina med prakso in registri: 15. vzporednice med slovensko in hrvaško etnologijo, ur. A. Svetel in T. Petrović Leš, 26-45. Knjižnica Glasnika Slovenskega etnološkega društva 53. Ljubljana: Slovensko etnološko društvo; Zagreb: Hrvaško etnološko društvo.

—. 2020. »Mitsko izročilo Mitskega parka.«V Mitski park: priročnikza izobraževanje; skupna čezmejna turistična destinacija za ohranjanje, varstvo in promocijo dediščine mitske pokrajine območja, ur. K. Hrobat Virloget, J. Đurkin Badurina, J. Rudan, N. Brubnjak, Š. Šedivy, E. Mihalič, E. Matijašić in A. Plestenjak, 3-27. http://mitski-park.eu/wp-content/uploads/ 2020/o9/FINAL-Priro\%C4\%8Dnik207A6120697A6F627261C5BE657661 6E6A65202D204D6974736B69207061726B2E706466.pdf

Hrobat Virloget, K., in N. Čebron Lipovec. 2020. "Povzetek analize za izobraževalne aktivnosti: projekt Mitski park.« http://mitski-park.eu/wp -content/uploads/2020/o5/DT1.1.2-Povzetek-analize-za-izobra\% $\mathrm{C}_{5}$ \%BEevalne-aktivnosti-slo-hrv-koncno-3.pdf. 
Hrobat Virloget, K., in P. Kavrečič. 2015a. »Mitska krajina Gropade v okviru ustnega izročila na Krasu in širše. V Nesnovna krajina Krasa, ur. K. Hrobat Virloget in P. Kavrečič, 69-84. Koper: Založba Univerze na Primorskem.

— . 2015b. »O sstari tradiciji« Krajine: predgovor.«V Nesnovna krajina Krasa, ur. K. Hrobat Virloget in P. Kavrečič, 13-18. Koper: Založba Univerze na Primorskem.

Jordan, P. 2003. Material Culture and Sacred Landscape: The Anthropology of the Siberian Khanty. Oxford: AltaMira Press.

Katičić, R. 2008. Božanski boj: tragovima svetih pjesama naše pretkršćanske starine. Zagreb: Ibis grafika; Moščenićka draga: Katedra Čakavskog sabora Općine Mošćenička Draga.

- 2011. Gazdarica na vratima: tragovima svetih pjesama naše pretkršćanske starine. Zagreb: Ibis grafika; Mošćenička Draga: Katedra Čakovskog sabora Općine.

Klemše, V., R. Petaros in A. Rupel. 1999. Goriško ozemlje (kartografsko gradivo): zemljevid in seznam krajevnih in ledinskih imen. Trst: Slovenski raziskovalni inštitut; Gorica: Narodna in študijska knjižnica.

Kockel, U. 2008. »Putting the Folk in Their Place: Tradition, Ecology, and the Public Role of Ethnology."Anthropological Journal of European Cultures 17 (1): 5-23.

Kovačič, G. 2021. »Rodiška mitska krajina: geografski vidik.«V Mitska krajina: iz različnih perspektiv, ur. K. Hrobat Virloget, 101-122 Koper: Založba Univerze na Primorskem.

Kravanja, B., 2007. Sveti svet: topografija religioznega prostora na primeru Breginjskega kota. Zbirka Županičeva knjižnica 23. Ljubljana: Filozofska fakulteta.

Kropej, M. 2008. Od ajda do zlatoroga: slovenska bajeslovna bitja. Celovec, Ljubljana in Dunaj: Mohorjeva.

Kvideland, R., 1993. "Establishing Borders: The Narrative Potential of a Motif.«V Boundaries \& Thresholds: Papers from a Colloquium of the Katherine Briggs Club, ur. H. E. Davidson, 13-20. Woodschester: Thimble.

Lapuente Martínez. L. 1971. Estudio etnográfico de Améscoa. Pamplona: Gobierno de Navarra.

Lévi-Strauss, C., 2004. Tristi tropici. Milano: Il Saggiatore.

Medeot, M., M. Crevato in A. Margon. 2021. »Arheologija spomina.«V Mitska krajina: iz različnih perspektiv, ur. K. Hrobat Virloget, 123-146. Koper: Založba Univerze na Primorskem.

Medvešček, P. 2015. Iz nevidne strani neba: razkrite skrivnosti staroverstva. Ljubljana: Založba Z RC.

Mencej, M. 2020. „Čarovništvo - diskurz ali praksa?« Studia mythologica Slavica 23:137-158. 
Mikhailov, N. 2002. Mythologia slovenica: poskus rekonstrukcije slovenskega poganskega izročila. Trst: Mladika in Knjižnica Dušana Černeta.

Panjek, A. 2015. Kulturna krajina in okolje Krasa. Koper: Založba Univerze na Primorskem.

Peisker, J. 1928. »Koje su vjere bili stari Slovjeni prije krštenja?« Starohrvatska prosjeta 2:1-36.

Peršolja, J. M. 200o. Rodiške pravce in zgodbe. Ljubljana: Mladika.

Placer, L. 2020. »Kulturno in zgodovinsko sporočilo Milanje (Slovenija).«Annales: Series historia et sociologia 30 (2): 215-234.

Pleterski, A. 2014. Kulturni genom: prostor in njegovi ideogrami mitične zgodbe. Zbirka Studia mythologica Slavica: Supplementa 10. Ljubljana: Založba ZRC.

- 2015. "Staroverstvo in pričevanja starovercev."V Iz nevidne strani neba, avt. P. Medvešček, 15-33. Zbirka Studia Mythologica Slavica: Supplementa 12. Ljubljana: Založba Z RC.

—. V tisku. "An Example of Scholasticism in the 21st Century."

Pogačnik, M. 2020. Elementarne sile in bitja Rodika. Ljubljana: Društvo za sožitje človeka, narave in prostora Vitaa.

Poljak Istenič, S. 2013. Tradicija v sodobnosti: Janče - zeleni prag Ljubljane. Ljubljana: Založba Z RC.

Race, H. 2020. »Rodiški miti v 40 tonah kamna. "Primorske novice, Sobota, 6. junij.

Rihtman Auguštin, D. 2001. Etnologija i etnomit. Zagreb: Naklada Publica.

Risteski, L. S. 2005. Kategorite prostor i vreme vo narodnata kultura na Makedoncite. Skopje: Matica Makedonska.

Scounti. 2009. "The Authentic Illusion: Humanity's Intangible Cultural Heritage; The Moroccan Experience."V Intangible Heritage, ur. L. Smith in N. Akagawa, 74-92. London: Routledge.

Severi, C. 2015. The Chimera Principle: An Anthropology of Memory and Imagination. Chicago, IL: Hau Books.

Sila, M. 1882. Trst in okolica: zgodovinska slika. Trst: Opravništvo »Edinosti«.

Slapšak, B. 1997. "Starejša zgodovina Rodika. V Rodik med Brkini in Krasom: zbornik ob 350. letnici cerkve, ur. M. Pregelj, 19-64. Koper: Ognjišče.

- 1999: "Slovenski Kras v poznejši prazgodovini in v rimski dobi.« V Kras: pokrajina, življenje, ljudje, ur. A. Kranjc, 145-163. Ljubljana: Založba ZRC.

Šešo, L. 2016. Živjeti s nadnaravnim bićima. Zagreb: Znanje.

Šmitek, Z. 2004. Mitološko izročilo Slovencev: svetinje preteklosti. Ljubljana: Študentska založba.

- 2008. »The Sacred Language of the Toponyms. «V Post-Yugoslav Lifeworlds, ur. Z. Šmitek in A. Svetieva, 13-35. Zbirka Županičeva knjižnica 15/1. Ljubljana: Filozofska fakulteta. 
. 2015. »Nočni bojevniki: kmečke herezije in čarovništvo na Slovenskem in v Furlaniji."V Nesnovna krajina Krasa, ur. K. Hrobat Virloget in P. Kavrečič, 35-48. Koper: Založba Univerze na Primorskem.

- 2019. Šelest divjine: zeleno dno našega kozmosa. Ljubljana: Beletrina. Toporov, V. N. 2002. Predzgodovina književnosti pri Slovanih: poskus rekonstrukcije. Zbirka Županičeva knjižnica 9. Ljubljana: Filozofska fakulteta. van der Port, M., in B. Meyer. 2018. »Introduction: Heritage Dynamics; Politics of Authentication, Aesthetics of Persuasion and the Cultural Production of the Real."V Sense and Essence: Heritage and the Cultural Construction of the Real, ur. M. van de Port in B. Meyer, 1-39. New York: Berghahn.

Van Gennep, A. 1981. Les Rites de Passage. Pariz: Picard.

Veyne, P. 1998. So Grki verjeli v svoje mite? Esej o konstitutivni imaginaciji. Ljubljana: Založba /*cf.

Vince-Pallua, J. 2018. „A Newly Discovered Figurative Representation of the Mythical Baba - 'Old Baba Vukoša' in St. Mary Church of Gračišće in Istria."V Sacralization of Landscape and Sacred Places, ur. J. Belaj, M. Belaj, S. Krznar, T. Sekelj Ivančan in T. Tkalčec, 105-116. Zagreb: Institute of Archaeology.

Young, S. 2020. »Public Bogies and Supernatural Landscapes in North-Western England in the 180os." Time and Mind 14 (4): 399-424.

\section{Mitska krajina: razmisleki in smernice za mitski park}

Članek obravnava nove vidike $\mathrm{v}$ raziskovanju mitske krajine na primeru skupne turistične destinacije Mitski park v Rodiku na Krasu in v Trebišćih pri Mošćenički Dragi. Preden lahko sploh analiziramo ohranjenost mitske krajine, je potrebno najprej razumeti, kako in zakaj se kolektivni spomin sploh ohranja v prostoru, kar avtorica pokaže v prvem delu, predvsem na osnovi razprav o materializaciji krščanskega kolektivnega spomina v Sveti deželi (Halbwachs 1971; 2001). Poleg materialnosti krajine, ki daje iluzijo o večnem trajanju, igra pomembno vlogo tudi plastenje dediščine, saj prek usidranja novih v stare tradicije prve pridobijo na avtoriteti in si prilastijo simbolni pomen starejše dediščine. Ob tem se sproža vprašanje različnih verovanjskih sistemov oziroma, po Veynu (1998), resničnostnih programov, ki se lahko nalagajo drug čez drugega v prostoru oziroma lahko tudi soobstajajo. O tem priča izročilo s Krasa, pri katerem so ob krščanskih apotropejskih znakih hkrati podali še starejše (Čok 2015). To dvojnost verovanj je mogoče pojasniti s trditvijo, da temelj verovanj ni prepričanje, ampak, prav nasprotno, dvom (Severi 2015), zato smo mnogokje priča različnim fluidnim verovanjskim identitetam, odvisnih od konteksta prostora in časa (Jordan 2003).

Pri analizi mitske krajine Rodika in Trebišć si avtorica najprej zastavi vpra- 
šanje o tem, kaj je "nadnaravno«. To je tudi eno izmed vprašanj na razstavi v Centru za obiskovalcu v Rodiku, ki prikazuje različne poglede na svet oziroma v angleščini worldmakings (van der Port in Birgit Meyer 2018, 2), od mitskega in znanstvenega do umetniškega in psevdoznanstvenega. Ali je "nadnaravno zgolj izmišljen koncept znanstvenega diskurza, ki se ne ujema s pojmovajem ljudi (Mencej 2020)? Prav primer »nadnaravnega« bitja lintverja z mesta Jezero na Čuku ponovno potrjuje tezo, da je Cerkev prav s svojo bitko proti »nadnaravnim « bitjem v resnici potrjevala njihov obstoj, pa čeprav jih je uradno negirala in prepovedovala verovanja $\mathrm{v}$ njih (Šešo 2016). Krščanski obredi in pripovedno izročilo o lintverju z Jezera nakazujejo verjetno nek predkrščanski kult prebivalcev arheološkega naselja Ajdovščina nad Rodikom, pri čemer na antropogene dejavnosti kažejo tudi veliki apnenčasti bloki, ki so tujki na brkinskem grebenu iz peščenjaka in laporovca. Če gledamo v kontekstu slovanske mitologije, pa bi lahko v demoniziranem bajnem bitju z vrha mitske Gore, polne vode, ki ustvarja bliske in nevihte, prepoznali nebeškega Peruna, gromovnika.

Analiza mitske krajine se nadaljuje v Trebišćih, ime katerih verjetno izhaja iz staroslovanske besede »treba«, žrtev, na mestu, ki se nahaja pomenljivo pod hribom z imenom staroslovanskega nebeškega gromovnika. V jamah pod Perunom je identificirano tudi mesto boga podzemlja in imetja Velesa in nedaleč stran več možnosti povezav v t. i. mitski trikotnik s staroslovansko žensko boginjo Mokošjo oziroma Babo (Katičić 2008, 305-312; Belaj in Belaj 2014, 157-166). Glede na pogosto omembo Peruna in njegovega trebišća v ruski cerkveni književnosti je zanimivo, da se enak vzorec toponimov v krajini pojavi tudi v Števerjanu/San Floriano del Collio na Goriškem v Italiji, kjer je hrib Kresavnik, ki pogosto nakazuje na gromovnikovo mesto, in pod njim Trebežišče (Klemše idr. 1999; Hrobat 2010a, 217). Primerjave so vidne tudi v zvezi z drugimi vzorci slovanskih mitskih krajin. Poleg slovanske mitske krajine toponimi Števerjana nakazujejo tudi primerjavo z rodiško večplastno mitsko krajino, predvsem v toponimih V sveti meji, Čuklja in dve Počivali, pri čemer se kaže nek mitski pomen imen, ki izvirajo iz besede Čuk.

Nadaljnje analize nadgrajujejo dosedanja spoznanja o mitskem liku Babe, ki jo prepoznamo tako $v$ slovanskem kot romanskem pripovednem izročilu in v krajini. Poleg doslej poznanih primerjav iz Italije in Francije so nakazane analogije s starko, babo v španskem pripovednem izročilu, ki se ravno tako navezuje ne dele krajine. Tolikšna razprostranjenost ustnega izročila o starkah, babah, najverjetneje nakazuje tudi njihovo arhaičnost. Žal izročila ni mogoče datirati, je pa to lažje, ko se izročilo navezuje na materialni svet. Najstarejša Baba kot kamnit monolit iz Istre na meji med Beneško republiko in Avstrijo je s pomočjo zemljevida datirana v 18. in 16. stoletje (glej zemljevid v Panjek 2015, 124), medtem ko je risba Babe v steno cerkve v Gračišću $\mathrm{v}$ Istri datirana v 15. stoletje (Vince-Pallua 2018). Analizirane so tudi mejne 
pozicije bab in njihova navezava na mitske toponime, ki izhajajo iz besede deva ter drugi toponimi. Po izročilih sodeč je baba temeljni element v kozmološkem sistemu, saj jo še danes najdemo v mnogih vaških prostorih. Med drugim je tudi ena izmed temeljnih točk v sistemu tročana pri t. i. starovercih (Medvešček 2015; Pleterski 2015). Avtorica hkrati opozarja na spremenljivost izročila in s tem tudi mitskih toponimov, ki se prav na primeru Babe iz Rodika izkažejo za nestalne in za predmet različnih interpretacij.

Analiza mitske krajine se zaključuje v nadgradnji spoznanj o "svetosti« katastrskih mej, na katerih folklorna in obredna izročila nakazujejo ne le stik med dvema vaškima prostoroma, temveč tudi stik med svetom živih in onstranskim svetom (Hrobat 2010a; Young 2020).

Poglavje se zaključuje s smernicami in problemi pri ohranjanju pripovednega izročila v Mitskem parku. Posebej je poudarjeno, da bo park, v kolikor bo pripovedno izročilo ostalo le $\mathrm{v}$ »okameneli« obliki sodobne prezentacije in ne bo (znova) zaživelo v pripovedovanjih ljudi, izgubil smisel. Avtorica posebej svari pred nevarnostmi banalizacije pripovednega izročila, napačnih interpretacij, ko se namesto o pripovednem ali mitskem izročilu napačno govori o mitih, ki v Evropi niso ohranjeni. Poudarja tudi pomen povezave pripovednega izročila s krajino. Zadnje svarilo velja povsem zmotnemu povezovanju mitskega izročila s sodobnimi nacionalnimi identitetami, pri čemer mora biti stroka še posebej kritično angažirana. Avtorica, ki je na podlagi raziskav v sodelovanju z lokalno skupnostjo zastavila Mitski park, se v zaključku sprašuje, koliko bo pripovedno izročilo, ki smo ga v parku »okameneli«, tudi zaživelo v svoji kreativnosti, spremenljivosti, torej, ali lahko dediščina spet postane tradicija? In kako se bo nesnovna dediščina spremenila $\mathrm{z}$ intervencijo turizma in etnologije?

\section{Mythical Landscape: Reflections and Guidelines for the Mythical Park}

The article discusses new aspects of research into the mythical landscape based on the example of the joint cross-border tourist destination, Mythical Park, in Rodik in the Karst region and in Trebišće near Mošćenička Draga. Before any analysis regarding the preservation of the mythical landscape, it is necessary to understand how and why the collective memory preserves itself in the space, which the author presents in the first part, mainly on the basis of discussions on the materialisation of Christian collective memory in the Holy Land (Halbwachs 1971; 2001). In addition to the material aspect of the landscape that creates the illusion of eternal duration, an important role is played by the stratification of heritage, because through the rooting of new traditions in ancient ones, the former gain authority and carry symbolic meaning of the older heritage. This raises the question of different belief systems or, according to Paul Veyne (1998), reality programmes that can be built on each other in space or can coexist. The evidence of this can be 
found in the Christian tradition of the Karst, in which other, older symbols were added to the Christian apotropaic symbols (Čok 2015). This dichotomy of belief can be interpreted by claiming that the foundation of belief is not conviction, but rather the opposite - doubt (Severi 2015), that is why we can witness a number of different fluid belief identities depending on the context of time and space (Jordan 2003).

By analysing the mythical landscape of Rodik and Trebišće, the author first asks herself what is the 'supernatural' that so often appears in the narrative tradition. This is also one of the issues of the exhibition at the Rodik Visitor Centre, which shows different views of the world or, in English, 'world makings' (van de Port, Birgit Meyer 2018, 2), from mythical, scientific to artistic and pseudo-scientific. Or is 'supernatural' just a fictional concept of scientific discourse that does not coincide with the people's perception (Mencej 2020)? The example of the 'supernatural' being Lintver, from the place of Jezero na Čuku, once again confirms the thesis that the Church, by its fight against 'supernatural' beings, actually confirmed their existence, although it officially denied them and forbade believing in them (Šešo 2016). Christian rites and the narrative tradition of Lintver from Jezero probably indicates a pre-Christian cult of the population of the ancient settlement at Ajdovščina above Rodik, whereby anthropogenic activities are evidenced in the large limestone blocks, unusual for the Brkini ridge, which is formed by sandstone and marl. If we look from the perspective of Slavic mythology, the demonised mythical creature from the top of the mythical mountain full of water could be interpreted as the heavenly god Perun, the creator of thunder who brings lightning and storms.

The analysis of the mythical landscape continues in the landscape of Trebišća, whose name probably derives from the Old Slavic word for sacrifice, 'treba,' and is located below the hill named after the Old Slavic celestial creator of thunder Perun. In the caves below it, the residence of Veles - the god of the underworld and livestock - was identified, as well as several possible connections in the so-called mythical triangle with the ancient Slavic goddess Mokoš or Baba (Katičić 2008, 305-312; Belaj in Belaj 2014, 157-166). Given the frequent mention of Perun and his location Trebišća in Russian ecclesiastical literature, it is interesting that the same pattern of toponyms in the landscape occurs in Števerjan/San Floriano del Collio in the Province of Gorizia in Italy, where the hill Kresavnik is located, which is often linked to the heavenly creator of thunder, as well as the place Trebežišče (Klemše idr. 1999; Hrobat 2010a, 217). Apart from the comparison with the Slavic mythical landscape, these toponyms also point to a comparison with the multi-layered mythical landscape of Rodik, especially with the toponyms $\mathrm{V}$ sveti meji, Čuklja and the two toponyms of Počivala, where a mythical connotation of the word Čuk is indicated.

Further analyses build on the previous knowledge about the mythical figure 
of Baba, which can be recognised in both the Slavic and the Romance narrative tradition and landscape. In addition to the comparisons known so far, based on examples from Italy and France, similarities with the old woman also exist in the Spanish narrative tradition which is also associated with some parts of the landscape. Such a prevalence of oral tradition concerning old women most likely indicates their archaic nature. Unfortunately, tradition cannot be dated, unlike cases where it refers to the material world. By using maps, the oldest Baba as a stone monolith from Istria, on the border between the Venetian Republic and Austria, dates back to the 18th and 16th century (see map Panjek 2015, 124), while the drawing of Baba on the church wall in Gračišće in Istria dates back to the 15th century (Vince-Pallua 2018). Further analyses were undertaken of the Baba boundary locations and their connection with mythical toponyms derived from the word 'deva' (meaning girl, a virgin) and other toponyms. According to tradition, Baba is a fundamental element of the cosmological system, as it is still found in many villages' areas today. Among other things, it is one of the fundamental points of the 'tročan' system in the so-called 'staroverci' tradition ('Old Faith Believers') (Medvešček 2015; Pleterski 2015). At the same time, the author draws attention to the changeability of the tradition, and thus the mythical toponyms, which, in the case of the Baba from Rodik, proved to be unstable and the subject of different interpretations.

The analysis of the mythical landscape ends with a revision of our knowledge regarding the 'sacredness' of cadastral boundaries, where folklore and ritual traditions indicate not only contact between two areas of neighbouring villages, but also contact between the world of the living and the dead (Hrobat 2010a; Young 2020).

The chapter concludes with guidelines and problems related to the preservation of the narrative tradition of the Mythic Park. It is especially emphasised that if the narrative tradition remains only in todays, 'petrified' form of presentation and does not come to life (again) in people's stories, then the park will lose its meaning. The author especially warns of the danger of trivialising the narrative tradition and misinterpretations, when instead of the narrative or mythical tradition, we are talking about myths that have not been preserved in Europe. She also emphasises the importance of the connection between narrative tradition and landscape. The last warning refers to the completely wrong connection between mythical tradition and contemporary national identities, where it is especially important the active critical engagement of the professionals. The author, who based on her research conceptually designed the Mythic Park in cooperation with the local community, concludes with the question to which extent the 'petrified' narrative tradition of the park will come to life in its creativity and variability, and whether heritage can become tradition again. And how will intangible heritage change under the influence of tourism and ethnology? 


\section{Mitski krajolik: razmišljanja i smjernice za Mitski park}

Članak razmatra nove aspekte $\mathrm{u}$ istraživanju mitskog krajolika na primjeru zajedničke turističke destinacije Mitski park u Rodiku na Krasu i u Trebišću kod Mošćeničke Drage. Prije bilo kakve analize očuvanja mitskog krajolika potrebno je razumjeti način i uzrok očuvanja kolektivnog pamćenja u prostoru, što autorica u prvom dijelu prikazuje uglavnom na temelju rasprave o materijalizaciji kršćanskog kolektivnog pamćenja u Svetoj zemlji (Halbwachs 1971; 2001). Uz materijalni aspekt krajolika koji stvara privid vječnog trajanja, važnu ulogu ima i slojevitost naslijeđa jer kroz ukorijenjenost novih tradicija u stare, prve stječu autoritet i prisvajaju simbolično značenje starije baštine. Pritom se postavlja pitanje različitih sustava vjerovanja ili, prema Paulu Veynu (1998), programa stvarnosti koji se u prostoru mogu nastavljati jedan na drugoga ili u njemu mogu koegzistirati. O tome svjedoči kršćanska predaja Krasa u kojoj su kršćanskim apotropejskim znakovima pridodani i drugi, stariji znakovi (Čok 2015). Ova podvojenost vjerovanja može se protumačiti tvrdnjom da temelj vjerovanja nije uvjerenost, već upravo ono suprotno, sumnja (Severi 2015), stoga svjedočimo brojnim različitim fluidnim identitetima vjerovanja ovisno o kontekstu prostora i vremena (Jordan 2003).

Analizirajući mitski krajolik Rodika i Trebišća, autorica si najprije postavlja pitanje što je to "nadnaravno« koje se tako često pojavljuje u narativnoj tradiciji. To je ujedno jedno od pitanja u sklopu izložbe u Centru za posjetitelje u Rodiku, koja prikazuje različite poglede na svijet ili, na engleskom, »worldmakings" (van de Port, Birgit Meyer 2018, 2), od mitskog, znanstvenog do umjetničkog i pseudoznanstvenog. Ili je »nadnaravno« tek izmišljeni koncept znanstvenog diskursa koji se ne podudara s konceptom ljudi (Mencej 2020)? Primjer »nadnaravnog « bića lintvera iz mjesta Jezero na Čuku još jednom potvrđuje tezu da je Crkva svojom borbom protiv "nadnaravnih" bića zapravo potvrdila njihovo postojanje, iako ih je službeno negirala i zabranjivala vjerovanje u njih (Šešo 2016). Kršćanski obredi i narativna tradicija lintvera iz Jezera vjerojatno upućuju na pretkršćanski kult stanovnika arheološkog naselja Ajdovščina iznad Rodika, pri čemu o antropogenim aktivnostima svjedoče i veliki vapnenački blokovi, neobični za pobrđe Brkina koje je građeno od pješčenjaka i lapora. U kontekstu slavenske mitologije, $\mathrm{u}$ demoniziranom mitskom biću s vrha mitske gore pune vode mogli bismo prepoznati nebeskog Peruna, gromovnika koji stvara munje i oluje.

Analiza mitskog krajolika nastavlja se u mjestu Trebišća čiji naziv vjerojatno potječe od staroslavenske riječi za žrtvu, »treba«, a smješteno je ispod brda nazvanog po staroslavenskom nebeskom gromovniku. U špiljama ispod Peruna identificirano je mjesto Velesa, boga podzemlja i stočarstva i nekoliko mogućnosti povezivanja u takozvanom mitskom trokutu s drevnom slavenskom ženskom božicom Mokoš ili Babom (Katičić 2008, 305-312; Belaj in Be- 
laj 2014, 157-166). S obzirom na često spominjanje Peruna i njegovog trebišća u ruskoj crkvenoj književnosti, zanimljivo je da se isti obrazac toponima u krajoliku javlja i u Števerjanu/San Floriano del Collio u Goričkoj pokrajini u Italiji, gdje se nalazi brdo Kresavnik koje se često označava kao gromovnikovo mjsto i mjesto Trebežišče, smješteno ispod brda (Klemše idr. 1999; Hrobat 2010a, 217). Osim usporedbe sa slavenskim mitskim krajolikom, toponimi upućuju i na usporedbu s višeslojnim mitskim krajolikom mjesta Rodik, posebno s toponimima V sveti meji, Čuklja i dva toponima Počivala, koji indiciraju mitski značaj toponima Čuk.

Daljnje analize nadovezuju se na dosadašnje spoznaje o mitskoj figuri Babe koju prepoznajemo kako u slavenskoj, tako i u romanskoj narativnoj tradiciji i krajoliku. Uz dosad poznate usporedbe s primjerima iz Italije i Francuske, sličnosti sa staricom postoje i u španjolskoj narativnoj tradiciji koja se također povezuje s nekim dijelovima krajolika. Takva rasprostranjenost usmene predaje o staricama najvjerojatnije ukazuje i na njihovu arhaičnost. Nažalost, predaja se ne može datirati, za razliku od slučajeva kada se predaja odnosi na materijalni svijet. Najstarija Baba kao kameni monolit iz Istre na granici između Mletačke Republike i Austrije datirana je uz pomoć zemljovida u 18. i 16. stoljeće (vidi zemljovid Panjek 2015, 124), dok je crtež Babe na zidu crkve u Gračišću u Istri datiran u 15. stoljeće (Vince-Pallua 2018). Izvršene su i analize graničnih položaja Baba i njihova povezanost s mitskim toponimima izvedenim iz riječi »deva« i drugim toponimima. Prema tradiciji, Baba je temeljni element kozmološkog sustava, kakav se i danas nalazi u mnogim seoskim područjima. Između ostalog, jedna je od temeljnih točaka sustava tročana kod tzv. starovjercima (Medvešček 2015; Pleterski 2015). Istodobno, autorica skreće pozornost na promjenljivost predaje, a time i mitskih toponima, koji su se, u slučaju Babe iz Rodika, pokazali nestabilnima i predmetom različitih interpretacija.

Analiza mitskog krajolika završava nadogradnjom spoznaja o "svetosti« katastarskih granica, gdje folklorna i obredna tradicija ukazuju ne samo na kontakt između dvaju seoskih prostora, već i na kontakt između svijeta živih i svijeta mrtvih (Hrobat 2010a; Young 2020).

Poglavlje završava smjernicama i problemima koji se odnose na očuvanje narativne tradicije u Mitskom parku. Posebno se naglašava da će, ako narativna tradicija ostane samo u današnjem, »okamenjenom " obliku prezentacije i (ponovno) ne zaživi u pričama ljudi, park izgubiti svoje značenje. Autorica posebno upozorava na opasnost od banaliziranja narativne tradicije, pogrešnih interpretacija, kada se umjesto o narativnoj ili mitskoj tradiciji govori o mitovima koji nisu sačuvani u Europi. Također naglašava važnost veze između narativne tradicije i krajolika. Posljednje upozorenje odnosi se na potpuno pogrešnu povezanost mitske tradicije sa suvremenim nacionalnim identitetima, pri čemu je naročito važan kritički angažman struke. Autorica, koja je na temelju istraživanja u suradnji s lokalnom zajednicom osnovala 
Mitski park, u zaključku se pita u kojoj mjeri će »okamenjena« narativna tradicija u parku zaživjeti i u svojoj kreativnosti i promjenjivosti, odnosno može li baština ponovno postati tradicija? A kako će se nematerijalna baština promijeniti pod utjecajem turizma i etnologije? 